Annales Missiologici Posnanienses t. 19 (2014), s. 37-77

DOI: $10.14746 /$ amp.2014.19.2

LEON NIEŚCIOR

Wydział Teologiczny Uniwersytetu Kardynała Stefana Wyszyńskiego

\title{
„Przybędą ze wschodu i zachodu [... ]". Augustyńska interpretacja Mt 8,11 i Łk 13,28-29 na tle starożytnej egzegezy
}

Działalność Jezusa w Galilei, w regionie gdzie wspólnie mieszkali Żydzi i poganie, niebawem nasunęła pytanie o zbawienie pogan. Uzdrowienie sługi setnika w Kafarnaum, osoby publicznej i dobrze znanej, wymagało pewnego komentarza. Chwaląc wiarę setnika, Jezus wypowiada następujące słowa w Mt 8,11-12: „Wielu przyjdzie ze wschodu i z zachodu i zasiądą do stołu z Abrahamem, Izaakiem i Jakubem w królestwie niebieskim. A synowie królestwa zostaną wyrzuceni na zewnątrz w ciemność; tam będzie płacz i zgrzytanie zębów". Tymczasem Łukasz nie umiejscawia powyższej wypowiedzi na początku działalności Jezusa, ale w czasie, gdy ,przemierzał miasta i wsie, nauczając i odbywając swą podróż do Jerozolimy” i gdy „ktoś Go zapytał: Panie, czy tylko nieliczni będą zbawieni?" (Łk 13,22-23). Wtedy Jezus udzielił dłuższej odpowiedzi, kończąc słowami: „Tam będzie płacz i zgrzytanie zębów, gdy ujrzycie Abrahama, Izaaka i Jakuba, i wszystkich proroków w królestwie Bożym, a siebie samych precz wyrzuconych. Przyjdą ze wschodu i zachodu, z północy i południa i siądą za stołem w królestwie Bożym. Tak oto są ostatni, którzy będą pierwszymi, i są pierwsi, którzy będą ostatnimi” (Łk 13,28-30). $\mathrm{W}$ polemice z pisarzem manichejskim Faustusem, którego zdaniem rozbieżności istniejące między Mt 8,11 a Łk 13,28-29 podważają autentyczność słów Jezusa $^{1}$, Augustyn przyznaje, że w Piśmie Świętym „na ten sam temat spotyka się wiele rozbieżności, ale nie zachodzą żadne przeciwieństwa"”2. Tymczasem obie

\footnotetext{
${ }^{1}$ Por. Augustyn z Hippony, Przeciw Faustusowi [księgi XXII-XXXIII], 33,3, thum. J. Sulowski, Warszawa 1991, PSP 56, s. 145. Skróty nazw patrystycznych serii wydawniczych - por. ogólny wykaz skrótów dla niniejszego rocznika.

2 Tamże, 33,8, s. 150.
} 
relacje synoptyczne są zgodne w zapowiedzi: dla jednych uczty eschatologicznej dzielonej z patriarchami, a dla drugich - odrzucenia. Większość komentatorów opowiada się za pochodzeniem logionu ze wspólnego dla synoptyków źródła Q, z tym że - zdaniem na przykład M. Birda - bardziej wierny oryginałowi jest tutaj przekaz Mateuszowy ${ }^{3}$. Biblista przedstawia kilka argumentów za autentycznością logionu, czyli pochodzeniem od samego Jezusa ${ }^{4}$.

Przedmiotem naszego badania jest interpretacja patrystyczna wskazanych powyżej słów Chrystusa. Zajmiemy się ich wykładnią przez ojców greckich i łacińskich, uwzględniając też pisarzy działających na pograniczu starożytności i średniowiecza. Sięgnęliśmy także do tekstów greckich Efrema Syryjczyka. Ponieważ na pierwszy plan wysuwa się w tej egzegezie Augustyn - około jednej trzeciej komentarzy pochodzi od niego - więc odpowiednio wyodrębnimy jego myśl i dokonamy konfrontacji z wykładnią pozostałych ojców. Zarówno interpretacja rozpatrywanego logionu przeprowadzona przez Augustyna, jak i innych komentatorów starożytnych, nie doczekała się studium u współczesnych badaczy patrystycznych. Znane są nam współczesne publikacje z dziedziny biblistyki na temat powyższych słów Jezusa, jednak nie występuje w nich wiele odniesień do wykładni patrystycznej.

Natknęliśmy się na wiele miejsc, w których autorzy zadowalają się samym przytoczeniem logionu, bez zgłębiania jego teologii. W naszym studium chodzi o wydobycie teologii biblijnej wyłaniającej się z komentarzy ojców. U obydwu ewangelistów przeciwstawia się status wybranych Żydów i innych wezwanych do zbawienia w następstwie niewiary tamtych. Ten kontrast retorycznie ukazuje Atanazy Aleksandryjski, twierdząc, że kiedy Izraelici zobaczą, jak inni zostali przyjęci na ucztę, a oni - odrzuceni, wtedy będą jeść własne ciała (por. Jr 19,9) - a więc, dodajmy, nie poprzestaną na zgrzytaniu zębami! Tymczasem każdy człowiek może zostać zbawiony, „stając się” w jakiś sposób „Izraelem”. Kwestia odrzucenia Izraelitów nie wchodzi w zakres naszej analizy, chyba że w komentarzach wiąże się ściśle z innymi wywodami.

Obietnica dana przez Jezusa dotyka istoty prawdy o Bożej woli powszechnego zbawienia. W tym sensie Euzebiusz z Cezarei nazywa tę zapowiedź „sło-

${ }^{3}$ Por. M.F. Bird, Who comes from the East and the West? Luke 13,28-29/ Matt 8,11-12 and the historical Jesus, „New Testament Studies” 52/4 (2006), s. 445; podobnie sądzi: D. Zeller, Das Logion Mt 8,11f/ Lk 13,28f und das Motiv der 'Völkerwallfahrt', „Biblische Zeitschrift“ [dalej cyt. jako BZ] 15/2 (1971), s. 224n.; nt. logionu por. też m.in.: J. Dupont, 'Beaucoup viendront du levant et du couchant...' (Matt 8,11-12; Lk 13,28-29), „Sciences Ecclésiastiques” 19/2 (1967), s. 153-167; M.E. Boring, A proposed reconstruction of Q 13,28-29, „Society of Biblical Literature Seminar Papers" 28 (1989), s. 1-22.

${ }^{4}$ Por. M.F. Bird, Who comes from the East and the West? ..., dz. cyt., s. 446-448.

${ }^{5}$ Por. Atanazy Aleksandryjski, Epistulae festales, 27, ed. L.Th. Lefort, Paris 1955, CSCO 151, s. 19. Tłumaczenia fragmentów dzieł patrystycznych na j. polski - LN, o ile nie zaznaczono inaczej. 
wem powszechnym" ( $\lambda$ ó $\left.{ }_{0} \varsigma \kappa \alpha \theta 0 \lambda \iota \kappa o ́ \varsigma\right)^{6}$. Epifaniusz z Salaminy wyjaśnia ją stwierdzeniem św. Pawła, że „u Boga nie ma względu na osobę” (Rz 2,11). On ,pragnie, by wszyscy ludzie zostali zbawieni i doszli do poznania prawdy” $(1 \mathrm{Tm} 2,4)^{7}$. Wobec odrzucenia przez jednych propozycję zbawienia składa innym, chcąc jednak zbawić wszystkich. Wola powszechnego zbawienia nie ma charakteru wtórnego, nie jest „awaryjnym” planem Boga. Odrzucenie przez Żydów jest okolicznością, w której ona pełniej się ujawnia. Jak wskazuje Kasjodor, gdyby nawet Izrael pozostał wierny swojemu Panu, obietnica Boża nie do końca spełniłaby się w tym jednym ludzie ${ }^{8}$.

Pismo Święte wyjaśniane przez siebie samo, Sciptura per Scripturam, wiele dopowie do owej zapowiedzi Jezusa, aczkolwiek, zdaniem D. Zellera, nie spotykamy szczególnego jej pokrewieństwa z jakimkolwiek tekstem starotestamentalnym ${ }^{9}$. Co do Nowego Testamentu, to na przykład przypowieść o winnicy wyraża ekonomię Bożą zapowiedzianą przez Jezusa w Łk 13,28-29 , znajdującą wyraz w powszechnym dostępie pogan do Bożych dóbr. Bóg postąpi zgodnie $\mathrm{z}$ werdyktem wskazanym przez słuchaczy przypowieści: „Nędzników marnie wytraci, a winnicę odda w dzierżawę innym rolnikom, takim, którzy mu będą oddawali plon we właściwej porze" (Mt 21,41) ${ }^{10}$. Jak podkreśla Euzebiusz z Cezarei, obrazem zbawczego uniwersalizmu Boga jest dzień Pięćdziesiątnicy w Jerozolimie, kiedy Duch Święty spoczął na przybyszów przybyłych ze wszystkich krajów (por. Dz 2,1-10). Wola zbawcza Boga obejmie wszystkie narody ziemi i dozna skutecznej realizacji. „Nie ma takiego narodu, takiej krainy, takiego rodu ludzkiego, takiego królestwa na całej zamieszkałej ziemi, które zgromadzone jako ludy Boże nie odpowiedziałyby na Jego wezwanie" ${ }^{11}$. Nasi komentatorzy wiele razy korzystają z innych świadectw biblijnych, aby zgłębić przesłanie rozpatrywanej zapowiedzi Jezusa.

Jan Chryzostom zwraca uwagę na akomodacyjny sposób mówienia Jezusa:

Aby te słowa nie zgorszyły słuchaczy, i aby nie dać im do tego żadnego powodu, na początku nie mówi o poganach, lecz zaczyna od setnika, aby nie wymieniać wyraźnie nazwy pogan. Nie powiedział bowiem: „Wiele narodów”, lecz: „Wielu ze wschodu i zachodu", co również oznaczało narody, ale nie raziło tak słuchaczy, bo myśl była ukryta. I nie tylko tak łagodzi to, co wydawało się nowością

${ }^{6}$ Euzebiusz z Cezarei, Commentaria in Psalmos, in Ps 112,7-9, PG 23, kol. 1352.

${ }^{7}$ Por. Epifaniusz Łaciński, Interpretatio Evangeliorum, 35, ed. A. Erikson, Lund 1939, s. 73.

${ }^{8}$ Por. Kasjodor, Expositio sancti Pauli Epistulae ad Romanos, 4, PL 68, kol. 435.

${ }^{9}$ Por. D. Zeller, Das Logion Mt 8,11f/ Lk 13,28f und das Motiv der 'Völkerwallfahrt' (Schluss), BZ 16/1 (1972), s. 84; z takim poglądem dyskutuje inny biblista, dostrzegając jednak w Starym Testamencie paralele: W. Grimm, Zum Hintergrund von Mt 8,11f/ Lk 1,28f, BZ 16/2 (1972), s. 255-256.

${ }^{10}$ Por. Anonim (Pseudo-Hieronim), Expositio Evangelii secundum Marcum, 12, ed. M. Cahill, Turnhout 1997, CCL 82, s. 52; Atanazy Aleksandryjski, Epistulae festales, 27, dz. cyt., s. 19.

${ }^{11}$ Euzebiusz z Cezarei, Commentaria in Psalmos, in Ps 67,31-33, dz. cyt., kol. 717. 
w Jego nauce, lecz również w ten sposób, że mówił o łonie Abrahama zamiast o królestwie. Ta nazwa przecież nie była im znana, a bardziej ich poruszało wspomnienie Abrahama. Dlatego również Jan nie od razu powiedział o piekle, lecz mówił o tym, co najbardziej ich zasmucało: „A nie myślcie, że możecie sobie mówić: «Jesteśmy dziećmi Abrahama»" (por. Mt 3,9; J 8,39). Oprócz tego zapobiega jeszcze czemuś innemu: aby nie zdawało się, że sprzeciwia się dawnemu stylowi życia. Gdyż kto podziwia patriarchów, kto ich łono nazywa losem sprawiedliwych, ten usuwa zupełnie tego typu podejrzenie ${ }^{12}$.

Nawiązanie do „łona Abrahama” wynika pewnie ze specyfiki greckiego tekstu Ewangelii, którym posługiwał się Złotousty. W każdym razie kaznodzieja wskazuje na ową pedagogię Chrystusa stopniowego przyzwyczajania Żydów do myśli o nowym wybraniu przez Boga ludzi. Zbawiciel mówi o nowych rzeczach, nie odrzucając całkowicie starych.

\section{Eklezjologia obietnicy}

Kim są ci, którzy przyjdą „ze wschodu i zachodu, z północy i południa”, by dostąpić udziału w królestwie Bożym? Cyryl Aleksandryjski, znany ze zdolności do syntezy patrystycznej wykładni Biblii, stwierdza, że słowo Boże bliżej nie określa tych ludzi. Niemniej jednak sam podejmuje próbę ich określenia. Za przychodzących „ze wschodu i zachodu” uznaje nie tyle samych świętych, ile tych, którzy razem z nimi przybędą do królestwa Bożego. Są nimi też ci, którzy stanowią przeciwieństwo niewiary Żydów, a więc - poganie, którzy uwierzyli, a których Bóg postawił ponad tamtymi. Poza tym do nich należą wszyscy inni zachowujący podobną postawę wiary ${ }^{13}$. Wydaje się, że przez owych „wielu” Cyryl rozumie wszystkich ludzi, którzy uwierzyli w Chrystusa i zostali dopuszczeni do wspólnoty zbawionych, niezależnie od tego, jak długo i kiedy zakończył się proces ich uzdalniania i dopuszczania do owej wspólnoty.

Ze względu na metaforyczność i dużą pojemność określenia „ze wschodu i zachodu" niektórzy nasi egzegeci włączają także świętych w to grono udających się w jakimś paradoksie na ucztę Abrahamową. Zdaniem Grzegorza z Elwiry odwołującego się do Orygenesa, zasiadającymi do wspólnoty z patriarchami są wszyscy święci, którzy zachowali wiarę Chrystusową ${ }^{14}$. Podob-

${ }^{12}$ Jan Chryzostom, Homilie na Ewangelię wedlug św. Mateusza, XXVI, 4, tłum. J. Krystyniacki, A. Baron, Kraków 2000, ŹMT 18, s. 321.

${ }^{13}$ Por. Cyryl Aleksandryjski, Commentarii in Lucam, in Luc. 13,29, PG 72, k. 780.

${ }^{14}$ Por. Grzegorz z Elwiry, Tractatus Origenis de libris Sanctarum Scripturarum, V, 37, ed. V. Bulhart, Turnhout 1967, CCL 69, s. 43. 
nie w przekonaniu Epifaniusza Łacińskiego przybywającymi na ucztę z patriarchami są „wszyscy święci ze wschodu i zachodu”, którzy zasiądą do stołu niebieskiego ${ }^{15}$. Nie rozróżniając między „gospodarzami” a „gośćmi” na tej uczcie, Grzegorz Oświeciciel zalicza do jej uczestników: „ojców, sprawiedliwych, proroków, Apostołów, męczenników i wszystkich wybranych Boga"16. Z czasem wyrażenie „wszyscy święci” nabierze charakteru technicznego, oznaczając anonimowych świętych, których razem Kościół wspomina w jedną uroczystość w swoim kalendarzu. Taka konotacja nie wydaje się obca przytoczonym komentatorom i dobrze się mieści w biblijnym kontekście rozpatrywanych słów.

Mateuszowy kontekst nadzwyczajnej wiary setnika, w którym padają słowa o wielu przybyłych ,ze wschodu i zachodu”, każe odnieść je do pogan przyjmujących Dobrą Nowinę przychylniej niż Żydzi. Wielu egzegetów tak właśnie je tłumaczy. Orygenes łączy zapowiedź o przyjściu do królestwa Bożego ludzi ,ze wschodu i zachodu” z przypowieścią o zaproszonych na ucztę (por. Mt 22,2-14). Zaproszonymi na ucztę są Żydzi, którzy nie przyjęli zaproszenia, natomiast zaproszonymi w drugiej kolejności, „na rozstajnych drogach", są poganie, którzy je przyjęli ${ }^{17}$. Przychodzącymi do królestwa są ci, którzy dzięki tajemniczej mocy Boga poznali, kogo mają kochać, jeśli nawet nikt ich o tym nie nauczał. Oni byli jak ci dobrzy słudzy, którzy wyglądali Pana, mając nadzieję, że zostanie zapowiedziane im Jego nadejście, aby mogli wypełnić Jego wolę, gdy ją poznają (por. Łk 12,36-40). „Pragnienie, by słuchać Słowa Bożego i szukać Jego woli, mają od Boga. To jest właśnie ten początek daru Bożego danego poganom, aby dzięki temu mogli przyjąć naukę prawdy"18. Tak oto prorocza obietnica wychodzi, poza Grekami i Rzymianami przychylnie przyjmującymi Ewangelię głoszoną przez Jezusa i apostołów, naprzeciw następnym pokoleniom, ludziom dobrej woli otwartym na wiarę, kolejnym ludom i narodom porzucającym pogaństwo.

Zdaniem na przykład Jana Chryzostoma, Jezus zapowiedział w Mt 8,11-12 powstanie „Kościoła pogan i odrzucenie Żydów”. Gdy wyrzekł tę zapowiedź, była ona jeszcze niezrozumiała. Nabrała większej jasności, gdy „Kościół pogan i odrzucenie Żydów" stały się faktem. Jezus chciał uczynić ją bardziej zrozumiałą, w przeciwnym razie niełatwo uwierzyliby w nią niewierzący. Dlatego poprzedził słowo konkretnym znakiem, uzdrawiając sługę setnika. Pro-

${ }^{15}$ Por. Epifaniusz Łaciński, Interpretatio Evangeliorum, 52, dz. cyt., s. 133.

${ }^{16}$ Agathangelus, Historia Armeniae, 23, ed. G. Lafontaine, La version grecque ancienne du livre Arménien d'Agathange, Louvain-la-Neuve 1973.

${ }^{17}$ Por. Orygenes, Commentarii in Matthaeum (fragmenta), 158, ed. E. Klostermann, E. Benz, Leipzig 1941, GCS 41/1, s. 79.

18 Pseudo-Klemens Rzymski w przekł. Rufina z Akwilei, Recognitiones, 4,4,6, ed. B. Rehm, F. Paschke, Leipzig 1965, GCS 51, s. 148. 
roctwo, które wypełnia się przez określone zdarzenie, zyskuje wiarygodność już w momencie wygłoszenia, kiedy zostaje potwierdzone jakimś znakiem. Dzięki wcześniejszemu znakowi wzbudza dużą wiarę, jeszcze zanim wypełni się sama rzecz ${ }^{19}$. Tak więc zdobywa wiarę dwukrotnie: kiedy zostaje wypowiedziane i kiedy spełnia się ostatecznie. Chryzostom sądzi, że proroctwo o zasiadających do stołu z patriarchami, chociaż zostało ,ppowiedziane ogólnie i o wielu innych, to jednak odnosi się również do nich [to jest uczniów Jezusa] oraz do niewiernych faryzeuszy" 20 .

Dla Augustyna przykładem napływu do królestwa Bożego ludzi ,ze wschodu i zachodu" są magowie, którzy prowadzeni znakiem gwiazdy na niebie odkryli w Jezusie kogoś więcej niż króla żydowskiego (por. Mt 2,2). Nie szukaliby tak gorliwie narodzonego w Betlejem króla Żydów, gdyby nie dostrzegli w Nim „króla wieków”. Podobnym przykładem jest Piłat, który kazał umieścić na krzyżu napis: „Jezus Nazarejczyk, Król żydowski” (J 19,19-22). Znamienne, że Piłat nie polecił napisać na krzyżu o Jezusie jako królu Greków i Rzymian, chociaż takim królem miał być w sensie duchowym, ale - jako królu Żydów, uznając Go rzeczywiście za takiego. Oni wszyscy, poganie, bardziej poznali się na Chrystusie niż Żydzi ${ }^{21}$. Dlatego będą mieli udział w uczcie królestwa niebieskiego, wszczepieni przez wiarę do wspólnoty z Abrahamem, Izaakiem i Jakubem, chociaż cieleśnie nie pochodzili od nich tak jak Żydzi ${ }^{22}$. Oprócz magów i Piłata jako przykład takiej postawy wśród pogan Augustyn podaje gdzie indziej setnika, niewiastę kananejską oraz pasterzy betlejemskich ${ }^{23}$.

Poza ścisłym kontekstem Ewangelii obraz przychodzących ,ze wschodu i zachodu" nabywa coraz szerszego zastosowania. Swoim zasięgiem wykracza stopniowo poza pogan, którzy uwierzyli ziemskim czynom i słowom Jezusa. Tymi przychodzącymi są ci, którzy uwierzyli dzięki przepowiadaniu apostołów; razem z patriarchami będą świętować w królestwie niebieskim ${ }^{24}$. Ci, którzy przyjdą ,ze wschodu i zachodu” i spoczną na łonie Abrahama, staną się jednym ludem wzywającym imienia Chrystusa i sami zostaną nazwani ku chwale Stwórcy Jego imieniem - „chrześcijanami”25. Żydzi będą ostatnimi, chrześcijanie pierwszymi ${ }^{26}$. Jak widzimy, wielu autorów przedstawia owo

\footnotetext{
${ }^{19}$ Por. Jan Chryzostom, In Isaiam, VII, 1, PG 56, kol. 77.

${ }^{20}$ Tenże, Homilie na Ewangelię wedlug św. Mateusza, LXIV, 4, dz. cyt., s. 268.

${ }^{21}$ Por. Augustyn z Hippony, Sermones, 201, 2, PL 38, kol. 1031; tenże, Sermo de passione Domini (218 auctus), 7, ed. R. Etaix, „Augustinianum” 34 (1994), s. 366.

${ }^{22}$ Por. tenże, Sermones, 201, 2, PL 38, kol. 1031.

${ }^{23}$ Por. tamże, 203,3, PL 38, kol. 1036.

${ }^{24}$ Por. Ireneusz z Lyonu, Adversus haereses, IV, 36,8, ed. A. Rousseau, B. Hemmerdinger, L. Doutreleau, Paris 1965, SCh 100, s. 919.

${ }^{25}$ Por. Hieronim ze Strydonu, Commentarii in Isaiam, XII, in 43,1-13, ed. M. Adriaen, Turnhout 1963, CCL 73A, s. 489.

${ }^{26}$ Por. Epifaniusz Łaciński, Interpretatio Evangeliorum, 55, dz. cyt., s. 147.
} 
przychodzenie „ze wschodu i zachodu” krok później. Poganie przestają być poganami $z$ chwilą przyjęcia wiary i chrztu, a obietnica Jezusa nie przestaje dalej spełniać się na nich. Zdaniem ojców, to w chrześcijanach zgromadzonych w społeczności Kościoła słowo Chrystusa spełnia się w najbardziej oczywisty sposób. Niektórzy, jak widzieliśmy, idą dalej i w doskonałych uczniach Chrystusa szukają spełnienia odnośnej zapowiedzi. Ireneusz z Lyonu dostrzega jej spełnienie po prostu w Kościele: „Jest więc oczywiste, że ci, którzy negują zbawienie Abrahama i wyobrażają sobie innego Boga niż Tego, który dał jemu obietnicę, są poza królestwem Boga jako pozbawieni dziedzictwa niezniszczalności, gdyż lekceważą i bluźnią Bogu, który wwiódł do królestwa niebieskiego Abrahama i jego potomstwo, to jest Kościół"27. Podobnie Orygenes wiąże z Kościołem przychodzących do królestwa Bożego „ze wschodu i zachodu”. Prorocy i ci wszyscy, „którzy od początku świata głosili Słowo Boże”, wprowadzają Kościół (lub duszę) jako Oblubienicę do domu Oblubieńca. „Do tego domu i na tę ucztę prorocy wiodą dusze, które ich słuchają i rozumieją"28. Wejść do królestwa Bożego (por. Łk 13,28), to przystąpić do społeczności Kościoła. Ci, którzy wejdą do Kościoła świętego i zostaną nazwani świętym imieniem, a więc przyjmą chrzest, otrzymają zadatek zmartwychwstania i łaskę szczęścia wiecznego ${ }^{29}$. Ambroży Autpert kojarzy Łk 13,28-29 z innymi słowami Jezusa: „w imię Jego głoszone będzie nawrócenie i odpuszczenie grzechów wszystkim narodom" (Łk 24,47). Przychodzący ze wszystkich stron świata, by zasiąść do uczty w królestwie, to ci, którzy uwierzyli słowu przepowiadania Ewangelii na całym świecie. Oni budują Kościół rozciągający się „,aż po cztery krańce nieba", oczekując nadejścia końca czasów ${ }^{30}$. Sens eklezjologiczny zapowiedzi Jezusa jest dla ojców jedną z największych oczywistości.

Tak samo jak inni, również Augustyn wiąże społeczność przychodzących „ze wschodu i zachodu” do królestwa niebieskiego ze wspólnotą Kościoła: „Oto Kościół Chrystusa, oto Jego stado”. Setnik z Ewangelii ilustruje takie przyjście ${ }^{31}$. „Synami królestwa” (Mt 8,12) są Żydzi, których czekają zewnętrzne ciemności. Tymczasem chrześcijanie wezwani do społeczności wiary będą razem z Abrahamem, Izaakiem i Jakubem karmić się sprawiedliwością i mądrością. Aktualizując słowa Ewangelii, biskup uświadamia swoim słuchaczom, że to oni są częścią tego ludu przychodzącego „ze wschodu i zachodu”

${ }^{27}$ Ireneusz z Lyonu Adversus haereses, IV, 8,1, dz. cyt., SCh100, s. 467.

${ }^{28}$ Orygenes, Komentarz do Pieśni nad Pieśniami, III, 6, tłum. S. Kalinkowski, Kraków 1994, s. $133 n$.

${ }^{29}$ Por. Ambroży z Mediolanu, De excessu fratris Satyri, 2, 116, ed. O. Faller, Wien 1955, CSEL 73, s. 316.

${ }^{30}$ Por. Ambroży Autpert, Expositio in Apocalypsin, IX, in 20, 8, ed. R. Weber, Turnhout 1975, CCM 27A, s. 759.

${ }^{31}$ Por. Augustyn z Hippony, Sermones, 46,34, ed. C. Lambot, Turnhout 1961, CCL 41, s. 559. 
i zajmującego swoje miejsce w królestwie Boga. Dalej wskazuje na moralne konsekwencje tej prawdy, że są „,ciałem Chrystusa" ${ }^{32}$.

W przekonaniu Augustyna zapowiedź Jezusa w Mt 8,11 par. spełnia się częściowo w aktualnej rzeczywistości Kościoła. Podobnie sądzi Hieronim. Żydzi jeszcze oczekują nadejścia Mesjasza, czasów pomyślności, powrotu ludów do swego Pana. Gdy zabrzmi głos Pana, zbiegną się Jego synowie z różnych stron świata (por. Oz 11,10-11). Chrześcijanie uważają zapowiedź prorocką za już częściowo spełnioną, ponieważ narody przybyły ze wszystkich stron świata i ciągle przybywają, aby dzielić wspólnotę ,z Abrahamem, Izaakiem i Jakubem"33. Zdaniem Hieronima, szczególnym momentem spełnienia się przepowiedni w Mt 8,11 była męka Pańska. Pękające skały podczas agonii Jezusa oznaczają kruszące się „twarde serca pogan”, a rozdarta zasłona przybytku (por. Mt 27,51) objawiła, że cokolwiek było zamknięte u proroków „zasłoną twardego Prawa, po jej rozerwaniu stanęło otworem przed poganami" ${ }^{34}$. Podobnie Chromacjusz z Akwilei wskazuje na zdarzenia paschalne, które rozpoczynają spełnianie się obietnicy. Chwaląc wiarę setnika, Jezus pokazał w Mt 8,11 przedmiot przyszłej nadziei ludów pogańskich. Zaczęła się spełniać po męce i zmartwychwstaniu Chrystusa, który następnie posłał swoich apostołów z Dobrą Nowiną do pogan. Przyszły więc narody ze wschodu i zachodu do królestwa Bożego, gdy po odrzuceniu niewiernego ludu żydowskiego został zgromadzony Kościół ze wszystkich ludów pogańskich. Dzięki swojej wierze i pobożności stały się godne udziału we wspólnocie świętych $\mathrm{w}$ niebie ${ }^{35}$. Nadając jednoznacznie eklezjalną interpretację zapowiedzi Jezusa w Mt 8,11, Beatus z Liebany stara się godzić wymiar aktualny i eschatologiczny zapowiadanego fenomenu. Królestwem niebieskim jest Kościół. Kościół jest właśnie tym „królestwem Ojca”. Co więcej, to Kościół obecny jest już „królestwem niebieskim”, gdyż w nim dostępuje się zbawienia „przez chrzest i mękę [Pańską]". Istnieje też jego wymiar eschatologiczny. Oznacza on zmartwychwstanie ciał, nastanie sprawiedliwości ${ }^{36}$. W sakramentach Kościoła rozpoczyna się obiecane zbawienie, którego pełnia nastąpi w wieku przyszłym.

Idea przystąpienia narodów do wspólnoty wiary w królestwie Bożym obecna jest w obrazie Syjonu. Już Izajasz prorokował o Jerozolimie: „Zaleje cię mnogość wielbłądów - dromadery z Madianu i z Efy. Wszyscy oni przy-

${ }^{32}$ Por. Augustyn z Hippony, Sermones, 62, 3, PL 38, kol. 417.

${ }_{33}$ Por. Hieronim ze Strydonu, Commentarii in prophetas minores, In Osee, III, in 10,11, ed. M. Adriaen, Turnhout 1969, CCL 76, s. 128n.

${ }^{34}$ Tenże, Listy, 120,8, tłum. J. Czuj, M. Ożóg, Kraków 2011, ŹMT 63, s. 64.

${ }^{35}$ Por. Chromacjusz z Akwilei, Tractatus in Mathaeum, 39, 2, ed. R. Étaix, J. Lemarié, Turnhout 1974, CCL 9A, s. 383n.

${ }^{36}$ Beatus z Liebany, Commentarius in Apocalipsin, 10, 3, 2-14, ed. H.A. Sanders, Romae 1930, s. 589. 
będą z Saby, zaofiarują złoto i kadzidło, nucąc radośnie hymny na cześć Pana" (Iz 60,6). W interpretacji tego obrazu, pomocnego w lekturze Mt 8,11 par., ujawnia się nie tylko sens eklezjologiczny, ale także, jak w powyższych wypowiedziach, relacja pomiędzy różnymi stadiami tegoż Kościoła.

U Hieronima, teologa Jerozolimy, spotykamy wypowiedzi, w których autor łączy oba wspomniane obrazy. Autor odnosi się do zapowiedzi Jahwe: „Oto Ja wybawię mój lud z krainy wschodu i z krainy zachodu słońca. Sprowadzę ich, i mieszkać będą w Jeruzalem. I będą moim ludem, a Ja będę ich Bogiem, wiernym i sprawiedliwym" (Za 8,7-8). Zdaniem egzegety, obietnica ta spełniła się częściowo przez to, że Izrael wrócił w czasach Zorobabela i Nehemiasza z niewoli babilońskiej do Judy i Jerozolimy (por. Ezd 2,2). Jednak teraz spełnia się w sposób szczególny i najpełniejszy pod panowaniem Zbawcy w Kościele, w prawdziwej Jerozolimie. To dokonujące się zbawienie ludu Jezus podobnie zapowiedział w Mt 8,11. Zgodnie z innym proroctwem, będzie tam od wschodu do zachodu, wszędzie, składana ofiara czysta Panu (por. M1 1,11) ${ }^{37}$. Tłumacząc typologicznie proroctwo Zachariasza, Hieronim odnosi je bardziej do Kościoła obecnego. Tymczasem w innej wypowiedzi ma na uwadze także przyszły Kościół. Stwierdza bowiem, że góra, na której gromadzą się wojska sprzymierzonych narodów przeciw Babilonowi, aby stać się narzędziem Bożego gniewu (por. Iz 13,1-6), jest tą samą górą, na którą przyjdzie mnóstwo narodów „ze wschodu i zachodu”, aby zasiąść do uczty w królestwie Bożym ${ }^{38}$. Choć sens eklezjologiczny nie jest tu wyraźny, to jednak wydaje się, że to z Kościołem, zarówno pielgrzymującym, jak i tryumfującym, autor utożsamia ową sprzymierzoną przeciwko złu i zwycięską społeczność.

Te same dwa wymiary Kościoła ma na uwadze Augustyn, również odwołując się do obrazu góry Syjon. Jego zdaniem, z jednej strony wierzący nie przybywają do świątyni w Jerozolimie ani do jakiegoś miejsca w centrum ziemskiej krainy, ani na jakąś górę, ale z drugiej strony w jakimś sensie przybywają do świątyni, do miejsca w centrum ziemi, do pewnej góry. Świątynią jerozolimską jest ciało Chrystusa, a centrum ziemi (medius locus) - sam Chrystus. Górą jest ta, o której mówi Izajasz: „Stanie się na końcu czasów, że góra świątyni Pańskiej stać będzie mocno na szczycie gór i wystrzeli ponad pagórki. Wszystkie narody do niej popłyną" (Iz 2,2). Górą schronienia jest Chrystus, który zasiada po prawicy Ojca ${ }^{39}$. W tej bogatej teologicznie wypowiedzi

${ }^{37}$ Por. Hieronim ze Strydonu, Commentarii in prophetas minores, In Zachariam, II, in 8,7-8, ed. M. Adriaen, Turnhout 1970, CCL 76A, s. 811.

${ }^{38}$ Por. tenże, Commentarii in Isaiam, VI, in 13, 4, ed. M. Adriaen, Turnhout 1963, CCL 73, s. 226.

${ }^{39}$ Por. Augustyn z Hippony, Sermones, 62A, „Miscellanea Agostina”, t. 1, Roma 1930-1931, s. 609. 
biskup Hippony ukazuje Kościół jako Mistyczne Ciało Chrystusa, a zarazem górę Syjon. Chrystus jest „centrum” całej ziemi, a Kościół - zapowiadaną górą zwycięstwa. Choć lokalizacja Jego tronu ,po prawicy Ojca” wskazywałaby na stadium ostateczne Kościoła, to z kolei idea „centrum ziemi” kazałaby odnieść metaforę do jego obecnej rzeczywistości.

Być może w powyższej wypowiedzi Augustyn polemizuje z milenaryzmem czy to żydowskim, czy chrześcijańskim, oczekującym doczesnego panowania Izraela przy końcu czasów, rozpoczynającego się od Jerozolimy. W duchu milenaryzmu chrześcijańskiego Ireneusz z Lyonu twierdził, że po nadejściu Antychrysta, który spustoszy ziemię i będzie panować trzy i pół roku, zasiadając w świątyni jerozolimskiej, zstąpi z niebios Syn Człowieczy i strąci w ogień Antychrysta i jego wiernych, i otworzy okres królowania sprawiedliwych, „dzień siódmy” odpoczynku. Nastąpi królestwo, o którym mowa w Mt $8,11^{40}$. W ten sposób sprawiedliwi będą panować na ziemi, przyzwyczajać się do objawienia chwały Ojca i doświadczać wspólnoty z aniołami. Sprawiedliwi, którzy przetrwali ucisk i nie ulegli bezbożności, oraz ci spośród pogan, których Pan odpowiednio przygotował, rozmnożą się na ziemi, a wywodzący się z pogaństwa pod władzą świętych oddadzą się służbie w Jerozolimie ${ }^{41}$. Jak widzimy, słowa Jezusa w Mt 8,11 par. nie zostały wyjęte z materii teologicznych sporów starożytności. Ich interpretacja pokazuje napięcia istniejące w ówczesnych dyskusjach na temat eschatologii.

Epifaniusz Łaciński wiąże słowa Jezusa z Mt 8,11 z Górą Błogosławieństw, także wskazując, choć pośrednio, na dwa etapy Kościoła. Wygłaszając na górze owe błogosławieństwa i zapowiadając nagrodę w niebie, Chrystus w jakimś sensie „dzięki tym kilku zdaniom zgromadził świętych [rozproszonych] po całym świecie na łonie patriarchy Abrahama jak gwiazdy na niebie" ${ }^{42}$. Być może komentator dostrzega w tle górę Syjon postrzeganą przez proroków jako miejsce zgromadzenia narodów i restytucji Izraela. Jezus wybiera symbolicznie i okazyjnie taką górę dla swojej nauki na znak przyszłej góry spełnienia się prorockich zapowiedzi. Przybywającymi na ucztę z patriarchami są ludzie z wielu pokoleń i narodów żyjący duchem błogosławieństw. Na końcu spełnią się one w ich życiu przez otrzymaną nagrodę.

Wychodząc poza metaforę Jerozolimy i góry Syjon, obraz ludów przychodzących ze wszystkich stron świata wyraża powszechność Kościoła. Odnosząc Łk 13,28 do Kościoła, Ambroży z Mediolanu używa wyrażenia ecclesia magna, przez co wskazuje na jego uniwersalny charakter. Kościół jest taki, bo

${ }^{40}$ Por. Ireneusz z Lyonu Adversus haereses, V, 30,4, ed. A. Rousseau, L. Doutreleau, C. Mercier, Paris 1969, SCh 153, s. 387.

${ }^{41}$ Por. tamże, V, 35,1, s. 439n.

42 Epifaniusz Łaciński, Interpretatio Evangeliorum, 36, dz. cyt., s. 74. 
zostaje zgromadzony ze wszystkich stron świata ${ }^{43}$. Uwagę naszych interpretatorów przyciąga motyw czterech stron świata, zarówno w sensie dosłownym, a więc geograficznym, jak i przenośnym. Oba sensy dotyczą tej samej rzeczywistości eklezjalnej, w jej wymiarze zewnętrznym i wewnętrznym. Zdaniem Augustyna, słowa Jezusa w Mt 8,11 spełniają się w jakiś dosłowny sposób na magach i Piłacie, bo magowie pochodzili ze Wschodu, a Piłat z Zachodu, ale spełniają się także w przenośny sposób, gdyż magowie byli obecni przy narodzinach Jezusa, a Piłat - przy śmierci, a więc przy „wschodzie” i „zachodzie” Jego życia ${ }^{44}$.

W komentarzach spotykamy przekonanie o dosłownym spełnieniu się obietnicy Jezusa mającym geograficzny wymiar. Jak stwierdza Euzebiusz z Cezarei, nie tylko setnik, ale całe sotnie, oddziały, co więcej, niezliczeni władcy, niezliczona rzesza ludzi i narodów przybędzie do Chrystusa jak ów setnik. Przybędą ze Wschodu, to jest z Indii, Persji, i dojdą do pełnej świętości, ku wstrzemięźliwości właściwej życiu filozoficznemu; przybędą wyznawcy Boży, którzy wyznają Chrystusa i przez nowe narodziny w Nim staną się dziećmi Abrahama. Podobnie przybędą z Zachodu: wszyscy Hiszpanie, Galijczycy, Maurowie, Afrykańczycy, zamieszkujący Ocean, Brytowie wyznający Chrystusa i Boga patriarchów. Wtedy poznają moc Logosu, który będzie głoszony po całym świecie. Jego zapowiedź w Łk 13,28-29 znajdzie potwierdzenie w nawróceniu wszystkich ludów ${ }^{45}$. Jednym z tych, w których spełniło się słowo Jezusa w Mt 8,11, jest dla Hieronima zamożny i szlachetnie urodzony Licyniusz z Boeticum, prowincji w południowo-wschodniej Hiszpanii, który postanowił wraz z żoną Teodorą wejść na drogę ascezy. Sfinansował kopistów, którzy zajęli się przepisywaniem ważniejszych dzieł Hieronima ${ }^{46}$. W nawiązaniu do geografii Kościoła powszechnego Augustyn dostrzega w Łk 13,28-29 zapowiedź nawrócenia się wielu ludów barbarzyńskich, tak iż Afryka nie będzie ostatnim regionem, w którym przyjmie się wiarę chrześcijańską ${ }^{47}$.

Mówiąc powyżej o ,życiu filozoficznym”, Euzebiusz z Cezarei prawdopodobnie miał na myśli monastycyzm, a przez „wyznawców Bożych” rozumiał pewnie męczenników. W życiu męczenników i mnichów dostrzegał więc spełnienie się rozpatrywanych słów Chrystusa. W ojczystej Palestynie był świad-

${ }^{43}$ Por. Ambroży z Mediolanu, Explanatio psalmorum XII, 23, 1, in Ps 39, ed. M. Petschenig, Wien 1919, CSEL 64, s. 228.

${ }^{44}$ Por. Augustyn z Hippony, Sermones, 201,2, PL 38, kol. 1031.

${ }^{45}$ Por. Euzebiusz z Cezarei, Theophania, IV, IV-V, ed. H. Gressmann, Leipzig-Berlin 1904, GCS 11/2, s. 169n.

${ }^{46}$ Por. Hieronim ze Strydonu, Listy, 71, 1, tłum. J. Czuj, M. Ożóg, Kraków 2010, ŹMT 55, s. 169 .

${ }^{47}$ Por. Augustyn z Hippony, Ad catholicos de secta Donatistarum, 15,37, ed. M. Petschenig, Wien 1909, CSEL 52, s. 279n. 
kiem trwałych owoców męczeństwa i rodzącej się siły monastycyzmu. Efrem Syryjczyk przytacza Mt 8,11, opisując w panegiryku świętość Juliana ascety, który doszedł do głębokiego poznania Boga, a był pochodzenia „barbarzyńskiego", bo wywodził się z pogańskiego Heliopolis koło Libanu ${ }^{48}$. Być może środowiskom chrześcijańskim końca IV wieku „wielu” przychodzących „,ze wschodu i zachodu" kojarzyło się z ludźmi napływającymi do Kościoła spoza świata grecko-rzymskiego. Obraz biblijny zostaje ubrany w wyobrażenie rzymsko-helleńskie i odniesiony do monastycyzmu.

Augustyn rozszerza eklezjalną perspektywę udziału nowych rzesz w dobrach królestwa Bożego. Rozumie alegorycznie „wschód” i ,zachód” w sensie dwóch podstawowych stanów w Kościele, bezżennego i małżeńskiego. Zarówno żyjący w dziewictwie i czystości, jak i w małżeństwie oraz w rodzinie, wszyscy będąc „członkami Chrystusa”, na końcu „zajaśnieją różnym światłem odpowiednio do swych zasług. Wszakże spodziewają się ci, którzy nie dla tego świata, ale dla Chrystusa byli małżonkami i ojcami, że stanie się ich wspólnym udziałem wielka chwała, czyli zasiadanie z Abrahamem, Izaakiem i Jakubem w królestwie Bożym"49. Biskup Hippony łączy uniwersalizm zbawienia z pluralizmem form życia w Kościele. Rozróżnienie geograficzne na Wschód i Zachód staje się obrazem różnorodności stanów w Kościele. W tym momencie przechodzimy z dosłownego, geograficznego sensu powszechności do jej sensu duchowego. Interpretacja Augustyna jest dość oryginalna, aczkolwiek w kontekście tego samego logionu, jak jeszcze zobaczymy, również Chryzostom stara się godzić obydwa stany ${ }^{50}$.

Pewna eksplikacja obrazu różnych stron świata, skąd przybywają nowi obywatele królestwa Bożego, łączy w sobie wymiar dosłowny i przenośny. Wyraża ideę zbawczej całości, kompletności. Anonimowy komentator dostrzega w czterech stronach świata, z których według Łk 13,29 przybywają ludzie na ucztę z patriarchami, obraz czterech Ewangelii. Przywołuje w tym kontekście jeszcze inny obraz, mianowicie rzeki, która wypływała z Edenu, ,aby nawadniać ów ogród, i stamtąd się rozdzielała, dając początek czterem rzekom" (Rdz 2,10). Źródłem jest Chrystus, cztery wypływające z Niego rzeki to Ewangelie. Irygacja ogrodu wyraża głoszenie Ewangelii po całym świecie przez ewangelistów, apostołów i innych nauczycieli wiary ${ }^{51}$. Już Ireneusz z Lyonu twierdził,

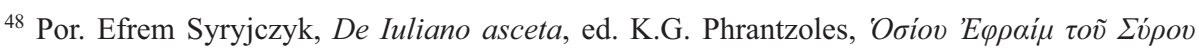
है $\rho \gamma \alpha$, t. 6, Thessalonica 1995 (repr.), s. 122.

49 Augustyn z Hippony, Wartości matżeństwa, 35, thum. W. Eborowicz, w: Antologia pism o matżeństwie i rodzinie, cz. 1, wyd. W. Eborowicz, Pelplin 1980, s. 86.

${ }^{50}$ Por. Jan Chryzostom, De virginitate, 82, ed. H. Musurillo, B. Grillet, Paris 1966, SCh 125, s. $382 \mathrm{nn}$.

${ }^{51}$ Por. Anonim, Quaestiones vel Glosae in evangelio nomine Quaestiones vel Glosae, 9, ed. R.E. McNally, Turnhout 1973, CCL 108B, s. 135. 
że liczba czterech Ewangelii wskazuje na ich pełnię i doskonałość ${ }^{52}$. Tak więc wschód, zachód, północ i południe obrazują owocność i skuteczność słowa Bożego ogarniającego cały świat. Powrót ludzi stamtąd na ucztę w królestwie staje się w pewnym sensie powrotem do raju. Wielość i bogactwo zrodzone przez głoszoną Ewangelię wraca jak rzeki do jednego nurtu.

Symbolika czterech stron świata wskazuje na powszechność zbawienia także w kontekście liczby dwunastu. Spotykamy ją już u Orygenesa, w nawiązaniu do rozmieszczenia w obozie dwunastu pokoleń Izraela w drodze do Kanaanu (por. Lb 2):

Również to, że opisane tu położenie obozu i układ jego wytyczenia ma ścisły związek z poszczególnymi pokoleniami, odnosi się w pewnej mierze do sytuacji, jaka nastąpi podczas zmartwychwstania umarłych. Chodzi mi o to, że stwierdzono, iż trzy pokolenia zostały umieszczone „od wschodu”, trzy „od zachodu”, trzy „od strony morza” i trzy ostatnie „od strony Akwilonu”, który się zwie „ostrym wiatrem”. Nie uważam też za rzecz małej wagi tego, że pokolenie Judy, które jest pokoleniem królewskim, zostało umieszczone „od wschodu”, skąd „wyszedł nasz Pan" (Hbr 7,14), i że połączono z tym pokoleniem pokolenia Issachara i Zabulona, i że trójka została przypisana każdej z czterech części obozu: choć położenie każdej z nich ma swoje własne, odrębne znaczenie, to jednak wszystkie obejmują liczbę Trójcy; i że w każdej z tych czterech części zawiera się ta sama, jedna liczba „trzy”, niewątpliwie dlatego, że pod jednym imieniem Ojca i Syna, i Ducha Świętego obliczani są wszyscy, którzy przybywają z czterech stron świata i wzywają imienia Pańskiego, ,zasiadając wraz z Abrahamem, Izaakiem i Jakubem w królestwie Boga" ${ }^{53}$.

Liczba po trzy pokolenia rozmieszczone w każdym z kierunków obozu symbolizują według Orygenesa Trójcę Świętą. Trzy (pokolenia) razy cztery (kierunki świata) daje dwanaście, czyli całkowitą liczbę pokoleń Izraela, a więc pełnię ludu Izraela. Powiązanie z Trójcą Świętą każe jednak rozszerzyć sens całej metafory, zwłaszcza jeśli mamy na uwadze osiedlenie się Izraela w Kanaanie: „Dziedzictwo przekazane przez Mojżesza i wyznaczone w Zajordanii w sensie tajnym i mistycznym w dwunastu pokoleniach synów Izraela symbolizuje cały rodzaj ludzki albo wszystkich ludzi, którzy doszli do poznania Boga" ${ }^{54}$. Tak więc obraz zostaje przeniesiony na lud Nowego Przymierza czy cały świat.

52 Por. Ireneusz z Lyonu, Adversus haereses, III, 11,8-9, ed. A. Rousseau, L. Doutreleau, Paris 1974, SCh 211, s. 160-176; Ambroży z Mediolanu, De Abraham, 2, 9, 65, ed. C. Schenkl, Wien 1897, CSEL 32/1, s. 619.

${ }_{53}$ Por. Orygenes, Homilie o Księdze Liczb, I, 3, tłum. S. Kalinkowski, Warszawa 1986, PSP 34/1, s. 36.

${ }^{54}$ Tamże XXVI, 4, s. 259. 
W interpretacji Orygenesa symbolika Ziemi Obiecanej podzielonej między dwanaście pokoleń Izraela ulega rozszerzeniu nie tylko w sensie przestrzennym, ale i czasowym. W powyższej wypowiedzi autor wyraźnie odnosi ją do momentu ,zmartwychwstania umarłych”. Obraz dzielonej między pokolenia Ziemi Obiecanej Aleksandryjczyk gdzie indziej jeszcze bardziej wiąże z rzeczywistością przyszłą, a mianowicie z obrazem nieba. Dostrzega pewną symetrię pomiędzy dziedzictwem ziemi a dziedzictwem nieba. Jak pokolenia Izraela otrzymały w przydziale określony region Ziemi Obiecanej, rozciągnięty czy to na wschód, czy zachód, północ czy południe (por. Joz 21), tak nastąpi pewien przydział sfery niebieskiej.

Otóż jak Bóg uszeregował gwiazdy niebieskie i rozmieścił je wedle jakichś cudownych i niewysłowionych zasad, jedne umieścił na osi północnej, inne po stronie wschodniej, inne na sklepieniu południowym, a jeszcze inne na zachodzie, tak samo, sądzę, i tych, którzy po zmartwychwstaniu umarłych będą ,jako gwiazdy niebieskie" w liczebności i chwale, bo pochodzą z nasienia Abrahama, być może rozmieści Bóg w królestwie niebieskim wedle układu gwiazd i stron świata, i jednym da dział na wschodzie, innym na zachodzie, innym na południu, a jeszcze innym, których zna, wyznaczy miejsce na północy, albowiem „wielu przyjdzie ze wschodu i z zachodu, z czterech stron świata, i zasiądą do stołu z Abrahamem, Izaakiem i Jakubem w królestwie niebieskim" ${ }^{\prime 5}$.

Być może przebija się delikatnie wątek osobistych spekulacji Orygenesa i jego hipotetyczny pogląd, że gwiazdy na niebie są bytami rozumnymi. Za nim idzie Epifaniusz z Salaminy, który podobnie w kontekście Łk 13,28 mówi o czterech regionach nieba i gwiazdach odpowiednio rozmieszczonych na firmamencie. Przy okazji robi wykład na temat ośmiu rodzajów wiatru, lokalizując je geograficznie, a także biblijnie ${ }^{56}$.

Alegorię dwunastu jako iloczynu liczby cztery oznaczającej strony świata i liczby trzy oznaczającej Trójcę Świętą przejmuje Augustyn. Jeszcze bardziej wiąże ją z ludem Nowego Przymierza.

I dlaczego wszystkich i zewsząd obejmuje liczba dwanaście? Dlatego bowiem, że używając słowa zewsząd, odnosimy to do całego świata. Otóż świat określa się przez znane cztery strony świata: wschód, zachód, południe i północ. Zewsząd wezwani w imię Trójcy, zarówno doskonali w wierze, jak i w prawie Trójcy, a trzy przez cztery daje dwanaście. Widzicie zatem, dlaczego święci pochodzą z całego

${ }^{55}$ Orygenes, Homilie o Księdze Jozuego, XXV, 4, tłum. S. Kalinkowski, Warszawa 1986, PSP 34/2, s. 133; por. tamże XXV, 3, s. 132.

${ }^{56}$ Por. Epifaniusz z Salaminy, De mensuris et ponderibus, 80, ed. J.E. Dean, Epiphanius' Treatise on Weights and Measures. The Syriac version, Chicago 1935, s. 77. 
świata, ci, którzy będą siedzieć na dwunastu stolicach i sądzić dwanaście pokoleń Izraela. Albowiem również dwanaście pokoleń Izraela, to pokolenia w liczbie dwunastu całego Izraela (por. Łk 22,30). Albowiem tak, jak mający sądzić są z całego świata, tak też i sądzeni są z całego świata ${ }^{57}$.

Cały świat, ze wschodu i zachodu, północy i południa, zostaje wezwany do wiary dzięki łasce Trójcy Świętej ${ }^{58}$. Na symbolikę biblijną dwunastki obejmującej dwanaście pokoleń starego Izraela nakłada się nowa symbolika wskazująca na kompletność nowego Izraela obejmującego cały świat, wszystkie narody i kultury. W tej pojemnej alegorii Augustyn nie ogranicza się do wskazania na kolegium dwunastu apostołów, na których opiera się Kościół, choć takie wskazanie pośrednio ma miejsce. Tymi dwunastoma są święci wszystkich czasów przychodzący z całego świata, którym Bóg oddaje we władanie swoje królestwo.

Wreszcie uwadze naszych komentatorów nie uchodzi słowo „wielu” charakteryzujące wezwanych do królestwa Boga. Jak podkreśla Ambroży z Mediolanu, nie będzie mało tych, którzy przyjdą, lecz wielu ${ }^{59}$. Zainteresowanie komentatorów ich liczbą wzmaga bezpośredni kontekst proroctwa Jezusa, które zostaje wypowiedziane według Łukasza w następstwie pytania: „czy tylko nieliczni będą zbawieni?" (Łk 13,23). Zresztą, Łukasz, relacjonując słowa Jezusa o przystępujących z całego świata do królestwa Bożego, nie używa słowa „wielu”, chociaż w jego relacji logion stanowi pewną odpowiedź na pytanie o liczbę zbawionych. Tymczasem słowo „wielu” pada u Mateusza, gdzie logion nie jest poprzedzony takim pytaniem. Orygenes powiada: „Pan nie powiedział tu, że «wszyscy» przyjdą" ${ }^{60}$. Gdzie indziej stwierdza:

Zwróćmy też uwagę, że powiedziano, iż wielu uwierzyło nie w Niego, ale w Jego imię. Ci, którzy wierzą w Niego, to ci, co idą wąską i ciasną drogą wiodącą do życia, a mało jest takich, którzy ją znajdują (por. Mt 7,14-15). Możliwe jednak, że wielu z tych, którzy wierzą w Jego imię, zasiądzie do stołu wraz z Abrahamem, Izaakiem i Jakubem w królestwie niebieskim, ponieważ „wielu przyjdzie ze wschodu i zachodu i zasiądzie do stołu z Abrahamem, Izaakiem i Jakubem w królestwie niebieskim”, to znaczy „w domu Ojca”, w którym ,jest mieszkań wiele” $(\mathrm{J} 14,2)^{61}$.

${ }^{57}$ Augustyn z Hippony, Objaśnienia Psalmów, 49,10, tłum. J. Sulowski, Warszawa 1986, PSP 38, s. 254.

${ }^{58}$ Por. Augustyn z Hippony, Sermones, 203, 3, PL 38, kol. 1036.

${ }^{59}$ Por. Ambroży z Mediolanu, De excessu fratris Satyri, 2,101, dz. cyt., s. 305.

${ }^{60}$ Orygenes, Komentarz do Listu św. Pawła do Rzymian, V, 5, tłum. S. Kalinkowski, Warszawa 1994, PSP 57/1, s. 275.

${ }^{61}$ Orygenes, Komentarz do Ewangelii wedlug św. Jana, X, XLIV, 311-312, thum. S. Kalinkowski, Kraków 2003, ŹMT 27, s. 279. 
Przytaczając podobnie na innym miejscu słowa Jezusa o ciasnej drodze, Orygenes stwierdza, że niewielu uwierzyło w Izraela i dlatego Jezus mówi do tych, którzy uwierzyli: „Nie bój się, mała trzódko, gdyż spodobało się Ojcu waszemu dać wam królestwo" (Łk 12,32) ${ }^{62}$. To ich ma na myśli Chrystus w słowach: „wielu jest powołanych, lecz mało wybranych” (Mt 22,14) ${ }^{63}$. Tymczasem mówi o wielu, którzy przyjdą do królestwa Bożego, zgodnie z Mt 8,11, ze względu na przyszłą wiarę pogan ${ }^{64}$. Aleksandryjczyk jest świadom trudności w pogodzeniu dwóch stwierdzeń Jezusa: jednego o niewielkiej liczbie uczniów podążających za Nim ciasną drogą, drugiego - o mnóstwie ludzi zbawionych. W swoich zdawkowych stwierdzeniach nie udziela pełnej odpowiedzi na powstające wątpliwości. Z jednej strony wie o słabym oddźwięku, z jakim spotkało się słowo Dobrej Nowiny za życia Jezusa. Liczy się z tym, że i następne pokolenia mogą $z$ oporem przyjmować Jego wymagającą naukę. Z drugiej strony wierzy, że poganie masowo przystąpią do wiary chrześcijańskiej. Ponadto, jeśli nawet wielu - jak to rozróżnia - uwierzy w Jego imię, a nie w Niego samego, czyli - jak może należałoby tłumaczyć - przyjmie wiarę powierzchownie, na przykład zadowoli się inicjacją chrzcielną, to jednak i tacy mogą w końcu zostać zbawieni. Niewykluczone, że natykamy się na ślady wiary Aleksandryjczyka w apokatastazę. Gdyby ktoś spodziewał się w interpretacji rozpatrywanych słów przez ojców wyraźnych akcentów apokatastycznych, to, jak widzimy, ich nie znajdzie, chyba że jedynie w formie niewyraźnej - u Orygenesa.

Augustyn powtarza ogólne stwierdzenie Orygenesa, że wielu przyjdzie „ze wschodu i zachodu, ale nie wszyscy" ${ }^{65}$. Także w samej refleksji nad liczbą współbiesiadujących z patriarchami inspiruje się prawdopodobnie Aleksandryjczykiem. Przytacza Mt 8,11 razem z innymi tekstami na potwierdzenie mnogości sprawiedliwych, gorliwych w czynieniu dobra (por. Tt 2,14), z których składa się apokaliptyczny thum tysięcy ludzi ubranych w białe szaty, z palmami w ręku (por. Ap 7,9). O ile teraz dobrzy i źli pozostają zmieszani jak pszenica i kąkol, o tyle „do stołu z Abrahamem, Izaakiem i Jakubem” zasiądą tylko wybrani przez Boga. Wybrani są zarówno liczni, jak i nieliczni. Są liczni, jeśli weźmie się ich samych $w$ sobie. $Z$ pewnością liczba zbawionych jest wielka, zwłaszcza jeśli uwzględni się także aniołów. Tymczasem wybrani są nieliczni w porównaniu z ludźmi złymi. Jeśli nawet potomstwo Abrahamowe w wierze jest tak liczne ,jak ziarnka piasku na brzegu morza" (Rdz 32,13), to jednak nie w tym sensie, że mamy wielu zdecydowanych na wszystko chrze-

\footnotetext{
${ }^{62}$ Por. Orygenes, Commentarii in Matthaeum (fragmenta), 157, dz. cyt., s. 78.

${ }^{63}$ Por. tamże, 466, s. 192.

${ }^{64}$ Por. tamże, 157, s. 78.

${ }^{65}$ Augustyn z Hippony, Sermones, 62, 3, PL 38, kol. 417.
} 
ścijan. Wielka liczba odnosi się do masy wiernych, słabych i cielesnych, którzy przyznają się do wiary w czasach pokoju i pomyślności, ale niczym piasek na brzegu zalany przez fale morskie zostają powaleni i przytłoczeni przez przychodzące prześladowania i utrapienia. Jeśli nawet sprawiedliwi są liczni jak gwiazdy na niebie (por. Rdz 22,17), to jednak w porównaniu z ziarnkami piasku są nieliczni. Gwiazdy oznaczają chrześcijan duchowych, a ziarnka piasku - chrześcijan cielesnych, twórców herezji i schizm... Mimo że w spichlerzu znajduje się wielkie mnóstwo ziarna, to jednak wydają się one nieliczne w stosunku do zebranej słomy. Chociaż Jezus unika odpowiedzi wprost na pytanie: „czy tylko nieliczni będą zbawieni?” (Łk 13,23), biskup Hippony odpowiada na nie twierdząco. Konsekwentnie powtarza, że liczba prawdziwych dzieci Boga jest mniejsza niż ludzi złych, w tym także złych chrześcijan. W argumentacji sięga po te same świadectwa biblijne co Orygenes, ale wprowadza też nowe. Niewielu przechodzi przez „ciasną bramę” (Mt 7,13). Za dowód na to, że nieliczni przystąpią do owej uczty, Augustyn uznaje postępowanie gospodarza w przypowieści o zaproszonych na ucztę, który wyprasza uczestnika nieposiadającego szaty godowej. Na podobne wykluczenie wielu ludzi z uczty wskazuje, zdaniem Augustyna, konstatacja Jezusa w tej przypowieści: „Bo wielu jest powołanych, lecz mało wybranych” (Mt 22,14) ${ }^{66}$. W szacunku liczby dopuszczonych do uczty z patriarchami stoi Augustyn, w porównaniu z Orygenesem, na drugim biegunie - i to, podobnie jak tamten, z racji swoich osobistych poglądów teologicznych. Znajdujemy tu dobry przykład na zależność egzegezy od poglądów teologicznych egzegety. Obaj zgadzają się co do dysproporcji pomiędzy zdecydowanymi na wszystko wyznawcami Chrystusa a całą resztą, tymczasem różnią się co do możliwości jej zbawienia.

\section{Eschatologia obietnicy}

Zdaniem Euzebiusza z Cezarei, Jezus złożył w Mt 8,11 największą swoją obietnicę ${ }^{67}$. Podobnie Augustyn nazywa tę zapowiedź „,wielką obietnicą, szczodrą zapłatą"68. Przedmiotem obietnicy jest uczta w królestwie Boga razem z innymi sprawiedliwymi. Po rozpatrzeniu kwestii, kim według naszych

${ }^{66}$ Por. tamże, 90,4, kol. 561; Augustyn z Hippony, Sermones, 88, ed. P. Verbraken, „Revue Bénédictine” 94 (1984), s. 96; Augustyn z Hippony, Sermones, 111, ed. C. Lambot, „Revue Bénédictine" 57 (1947), s. 115; Augustyn z Hippony, Epistulae, 93,9, ed. A. Goldbacher, Wien 1898, CSEL 34/2, s. 475; Augustyn z Hippony, Contra Cresconium, 3,66,75, ed. M. Petschenig, Wien 1909, CSEL 52, s. 480n.; tamże, 4,53,63, s. 560n.

${ }^{67}$ Por. Euzebiusz z Cezarei, Theophania, IV, IV, dz. cyt., s. 168.

${ }^{68}$ Augustyn z Hippony, Sermones, 104, w: Sancti Aurelii Augustini Sermones selecti duodeviginti, ed. C. Lambot, Utrecht 1950, SPM 1, s. 58. 
komentatorów jest „wielu” przybywających „,ze wschodu i zachodu, z północy i południa", pora rozpatrzyć cel ich przybycia, a więc i przedmiot Bożej obietnicy.

Zwróćmy uwagę na towarzystwo mężów Starego Przymierza, w którym zaproszeni będą przebywać. Mateusz i Łukasz wymieniają po imieniu trzech patriarchów, natomiast Łukasz rozszerza tę społeczność o proroków. Wierzący w Chrystusa zostają uznani ,za godnych królestwa wiecznego razem z patriarchami i prorokami" 69 . Przybywający na ucztę z patriarchami z pewnością zastaną tam też innych: proroków, apostołów, męczenników, wraz z aniołami, archaniołami i wszystkimi mocami niebieskimi ${ }^{70}$. Wspólnota przybyłych ,ze wschodu i zachodu" ze społecznością patriarchów pokazuje jedność dwóch Przymierzy, Starego i Nowego, których nie należy sobie przeciwstawiać, jak to czynili gnostycy, bo są dziełem tego samego Boga ${ }^{71}$. W przybyciu do wspólnego stołu w królestwie niebieskim wypełnia się spójna i ciągła ekonomia Boga.

Po gnostykach także manichejczycy podważali jedność dwóch Testamentów. Przeciwstawianie Starego Przymierza Nowemu stoi w tle manichejskich poglądów Faustusa na temat wiary i sprawiedliwości Abrahama, z którymi polemikę podejmuje w kontekście Mt 8,11 par. Augustyn. Faustus deklaruje, że nikomu nie zazdrości zbawienia, ale uważa, że patriarchowie, wedle samego świadectwa Biblii, „byli ludźmi niezwykle występnymi”. Jeśli Bóg zmiłował się nad nimi, to nie z powodu ich zasług, ale swojego miłosierdzia. „Niechaj będą w miejscu, jakiego nigdy się nie spodziewali ani w które nie wierzyli, [...] byle tylko było rzeczą jasną [...], że [będą tam] po długim okresie przebywania w ciemnym i za karę piekielnym miejscu pod strażą, gdzie pokutowali za przewiny życia, skąd zostali wybawieni przez Pana naszego Chrystusa" 72 . Faustus twierdził, że „przed przyjściem Pana naszego wszyscy patriarchowie Izraela i prorocy przebywali w ciemnościach piekieł stosownie do tego, na co zasłużyli" "73. Nie wchodząc w spór na temat stanu szczęśliwości na tamtym świecie, Augustyn broni sprawiedliwości Abrahama i patriarchów na podstawie świadectw biblijnych oraz podkreśla jego wiarę ${ }^{74}$.

Podobnie Jan Chryzostom broni zasług Abrahama i zaszczytu ucztowania $\mathrm{w}$ jego towarzystwie. Jego apologia patriarchy nie dokonuje się jednak na

${ }^{69}$ Justyn Męczennik, Dialog z Żydem Tryfonem, 120,6, thum. L. Misiarczyk, Warszawa 2012, s. 295.

${ }^{70}$ Epifaniusz Łaciński, Interpretatio Evangeliorum, 52, dz. cyt., s. 133.

71 Por. Epifaniusz z Salaminy, Panarion, 23,6, ed. K. Holl, Leipzig Berlin 1915, GCS 25, s. 254 n.

${ }^{72}$ Augustyn z Hippony, Przeciw Faustusowi [księgi XXII-XXXIII], 33,1, dz. cyt., s. 142n.

${ }^{73}$ Por. tamże, 33,3, s. 145.

${ }^{74}$ Por. tamże, 33,5, s. 146n. 
tak zasadniczym gruncie, ale w kontekście sporu o cnotę wstrzemięźliwości. W związku z Mt 8,11 par. Złotousty odnosi się do poglądu tych, którzy sądzili, że praktykującym dziewictwo przysługuje inne miejsce niż łono Abrahama. Patriarcha bowiem był żonaty, miał dzieci, majętność, a bezżenni dla królestwa Bożego wyrzekli się tego wszystkiego. Jakim wyróżnieniem dla bezżennych apostołów, Jana, Pawła i innych, może być wspólnota z żonatymi? Owszem, zdaniem Złotoustego, apostołom przysługuje w niebie zaszczytniejsze miejsce niż łono Abrahama: będą zasiadać na dwunastu tronach (por. Mt 19,28) i sądzić potomstwo patriarchów. Niemniej jednak dla pozostałych zostaje przewidziana jakaś bezpośrednia wspólnota z Abrahamem. Tym, co łączy wszystkich, nie jest zewnętrzne dziewictwo i wstrzemięźliwość, ale duchowa wolność od pożądania. Pod tym względem Abraham nawet wyprzedził innych, bo opanował namiętności bardziej niż ci, którzy ślubują dziewictwo. Potrafił na przykład oddalić ze swego domu nałożnicę (por. Rdz 21,12), aby zapobiec wszelkim kłótniom i nieporozumieniom ${ }^{75}$.

Tak więc łączy uczestników uczty eschatologicznej wspólna nagroda z Abrahamem, Izaakiem i Jakubem. Wskazuje na nią Orygenes, wyjaśniając Mt 8,11 w powiązaniu z przypowieścią o robotnikach zaproszonych do winnicy o różnej porze (por. Mt 20,1-16). Przypowieść kończy się podobną konstatacją jak u Łukasza, zapowiedzią Jezusa o wspólnej uczcie z Abrahamem: „Tak ostatni będą pierwszymi, a pierwsi ostatnimi” (Mt 20,16; por. Łk 13,30). Różne pory dnia, w których zostają wezwani robotnicy, mogą symbolizować wiek nawrócenia. Może ktoś zwrócić się ku Bogu za młodu, w wieku dojrzałym albo na starość. Denar oznacza nagrodę królestwa, ponieważ jest na nim wyryta podobizna króla. Komentator szuka jeszcze innego znaczenia trzech pór dnia w przypowieści. Mogą one wskazywać na tych, „którzy już od samego zaistnienia życia po koniec świata uznani zostali za godnych powołania do życia wiecznego", a dokładnie - na różne okresy w historii zbawienia i społeczności sprawiedliwych. Przybyli do winnicy o poranku oznaczają tych, którzy na samym początku zostali powołani do kultu Bożego. Do nich należy między innymi Henoch, Noe i jemu współcześni. Przybyli w południe, o trzeciej, to Abraham i jemu współcześni. Przybyli o szóstej to ci, którzy żyli w czasach proroków. Godziny dziewiątej Orygenes nie wykorzystuje dla swojej symboliki - przynajmniej w zachowanym scholium. Przybyli o jedenastej oznaczają ludzi, którzy narodzili się po przyjściu Chrystusa. Oni wszyscy dostąpią nagrody jednego denara, czyli wejdą do królestwa Bożego ${ }^{76}$. Pewnie za Orygenesem powtarza tę wykładnię - z drobną modyfikacją - Cyryl Aleksandryjski. Uwzględnia wszystkie pięć pór, w które wychodził gospodarz, by werbować

\footnotetext{
${ }^{75}$ Por. Jan Chryzostom, De virginitate, 82, dz. cyt., s. 382nn.

${ }^{76}$ Por. Orygenes, Scholia in Lucam, in Luc. 13,29, PG 72, kol. 360n.
} 
robotników. Robotnikiem najętym wcześnie rano był Adam w raju, o trzeciej godzinie - Noe, o szóstej - Abraham, o dziewiątej - Mojżesz i prorocy. „Co do jedenastej godziny, czyli o porze piątej, to gdy dzień się już chylił, nadszedł obecny wiek, kiedy Chrystus najął pogan, albowiem nikt inny poza Nim nie wezwał ich do poznania”. W myśl Łk 13,30 ci ostatni, o których teraz można sądzić, że zajmują miejsce ostatnie, zajmą miejsce pierwsze dzięki wierze, ponieważ poznali Boga na samym końcu ${ }^{77}$. W społeczności tych, którzy uwierzyli, panują zasady miłosierdzia, natomiast od niewierzących egzekwuje się sprawiedliwość.

W Abrahamie Bóg godzi pewne pozorne sprzeczności, jak te, które głosili gnostycy co do Starego i Nowego Przymierza. W nim też zostaje przezwyciężony konflikt pomiędzy pierworództwem z natury i wybraniem $\mathrm{z}$ upodobania, obrzezaniem i nieobrzezaniem. W katenach Prokopa z Gazy spotykamy bogatą refleksję na temat wybrania przez Boga, w świetle pewnego wymogu Prawa: „Jeśli jakiś mąż będzie miał dwie żony, jedną kochaną, a drugą niekochaną, i one urodzą mu synów - kochana i niekochana - a pierworodnym będzie syn niekochanej, to w dniu przekazywania dziedzictwa nie może za pierworodnego uznać syna kochanej, gdy pierworodnym jest syn niekochanej" (Pwt 21,15-16). „Synagoga Żydów” jest podobna do pierworodnego syna niewiasty niekochanej, podczas gdy „Kościół pogan”, czyli chrześcijanie wywodzący się z pogaństwa, podobni są do syna umiłowanej żony, ale nie pierworodnego. Na końcu czasów Bóg odpłaci każdemu według ich czynów, a ci, którzy zachowali swoje pierworództwo dzięki wierze, dostąpią udziału w królestwie Ojca zgodnie $\mathrm{z}$ Mt 8,11, i to $\mathrm{z}$ dwóch powodów: że urodzili się przed nadejściem łaski przychodzącej na świat $\mathrm{w}$ osobie Zbawiciela; że mimo to prowadzili ewangeliczne życie i złożyli świadectwo wiary. Takim właśnie był Abraham, który nigdy nie utracił pierworództwa w wierze. To na łonie Abrahama, Izaaka i Jakuba, czyli sprawiedliwych Starego Przymierza, spoczną wszyscy zbawieni, a więc i chrześcijanie wywodzący się z pogaństwa, którzy nie nosili od początku znaku wybrania. Dostąpią wspólnoty z Abrahamem, tym bardziej że on także przez jakiś czas nie miał obrzezania i nie żył w formalnym przymierzu z Bogiem. Powiada św. Paweł:

I otrzymał znak obrzezania jako pieczęć usprawiedliwienia osiągniętego dzięki wierze, którą miał wtedy, gdy jeszcze nie był obrzezany. I tak stał się ojcem wszystkich tych, którzy nie mając obrzezania, wierzą, by również im poczytano to za tytuł do usprawiedliwienia, a także ojcem tych obrzezanych, którzy nie tylko na obrzezaniu się opierają, ale nadto kroczą śladami tej wiary, jaką ojciec nasz, Abraham, miał przed obrzezaniem (Rz 4,11-12).

${ }^{77}$ Por. Cyryl Aleksandryjski, Commentarii in Lucam, in Luc. 13,29, PG 72, kol. 780n. 
W ten sposób stał się ojcem wszystkich wierzących, obrzezanych i nieobrzezanych $^{78}$. Zasiądą więc $\mathrm{z}$ nim do stołu w królestwie Boga wszyscy zbawieni.

Abraham i inni patriarchowie nie są więc na uczcie w królestwie Bożym jedynie współbiesiadnikami. Oni w jakiś sposób pośredniczą w udzielaniu tam dóbr. Obietnica w Mt 8,11 jest konsekwencją obietnicy danej Abrahamowi, że będzie „ojcem mnóstwa narodów” (Rdz 17,4) ${ }^{79}$. One dostąpią dóbr wiecznych na skutek dziedziczenia i ojcowskiego błogosławieństwa. W kulturze biblijnej dziedziczył najstarszy syn. W tym miejscu wyłania się problem synostwa i pierworództwa. W dobrach Abrahamowych udział będą mieli jego potomkowie. Nasi komentatorzy przejmują tego rodzaju metafory biblijne, aby wskazać na rolę Abrahama w społeczności zbawionych. Jak podkreśla Augustyn, ci przychodzący ,ze wschodu i zachodu” stają się w jakiś sposób dziećmi Abrahama.

Nie zrodził ich ze swego ciała Abraham. A przychodząc zasiądą wraz z nim do stołu w królestwie i staną się jego dziećmi. Dlaczego jego dziećmi? Nie dlatego, że pochodzą od niego cieleśnie, ale że naśladują jego wiarę. „A synowie królestwa”, to znaczy Żydzi, ,zostaną wyrzuceni na zewnątrz w ciemność; tam będzie płacz i zgrzytanie zębów". Wyrzuceni zostaną na zewnątrz w ciemności ci, którzy cieleśnie pochodzą od Abrahama, a wspólnie z nim zasiądą do stołu w królestwie niebieskim ci, którzy naśladowali wiarę $\mathrm{Abrahama}^{80}$.

Podobnie Jan Chryzostom sądzi, że nie przez pokrewieństwo fizyczne, ale duchowe, przez podobny sposób życia, przybywający ,ze wschodu i zachodu" będą dzielić z Abrahamem miejsce spoczynku ${ }^{81}$. Czyniąc aluzję do słów: „Jeżeli zaś jesteśmy dziećmi, to i dziedzicami” (Rz 8,17a), wskazuje na dziedziczenie jako konsekwencję synostwa: „Czy widzisz, jak stopniuje dar? Ponieważ możliwą jest rzeczą być dzieckiem, a nie zostać dziedzicem (przecież nie wszyscy potomkowie dziedziczą), dodaje nadto, że są dziedzicami. Żydzi zaś mało, że nie mieli takiego synostwa, ale zostali także pozbawieni dziedzictwa" 82 . Gdy przeminie obecny świat, święci posiądą razem z patriarchami królestwo świętych i doznają wyzwolenia wraz z całym stworzeniem. To właśnie oznacza błogosławieństwo udzielone Józefowi przez Jakuba

${ }^{78}$ Por. Prokop z Gazy, Commentarii in Octateuchum, in Deut. 21,16, PG 87/1, kol. 925.

${ }^{79}$ Kasjodor, Expositio sancti Pauli Epistulae ad Romanos, 4, PL 68, kol. 435.

${ }^{80}$ Augustyn z Hippony, Objaśnienia Psalmów, 46,12, dz. cyt., PSP 38, s. 204.

${ }^{81}$ Por. Jan Chryzostom, Ad viduam iuniorem, 3, ed. G.H. Ettlinger, B. Grillet, Paris 1968, SCh 138, s. 130.

82 Jan Chryzostom, Homilie na List św. Pawła do Rzymian, XIV, 3, tłum. T. Sinko, t. 1, cz. 1, Kraków 1995, s. 221. 
(por. Rdz 48-49) ${ }^{83}$. Członkowie nowego ludu dostępują błogosławieństwa Abrahamowego, współdziedzicząc je ze swymi ojcami. Otrzymują je w Chrystusie, stając się wielkim mnóstwem i zgromadzeniem spośród ludów pogańskich $^{84}$. Potomstwem Abrahama jest „Kościól, który przez Jezusa Chrystusa otrzymuje adopcję i dziedzictwo obiecane Abrahamowi"85. Przyjmując do siebie „pierwociny Izraela”, Kościół z kolei staje się matką dwóch ludów, podobnie jak Rebeka była matką dwóch synów, Jakuba i Ezawa. Chrystus z dwóch ludów czyni niejako nowego człowieka ${ }^{86}$.

Reminiscencję epizodu z Jakubem i Ezawem znajdujemy u Augustyna. Obrazem Kościoła jest nie tyle Jakub i Ezaw, którzy powyżej oznaczają dwa ludy, czyli Żydów i pogan, ile sam Ezaw. Jezusową zapowiedź udziału w królestwie Bożym powołanych spoza Izraela kojarzy Augustyn z historią pierworództwa Ezawa, odebranego podstępnie przez Jakuba (por. Rdz 25,27-34). Gdyby epizod wziąć dosłownie, oznaczałby popełnienie oszustwa. Tymczasem jego interpretacja alegoryczna niesie budujące przesłanie, gdyż wskazuje na społeczność Kościoła, który przejął od Izraela status ludu wybranego. „«Tak ostatni będą pierwszymi, a pierwsi ostatnimi» (Mt 20,16 par.). Tak bowiem jakimś sposobem młodszy brat odebrał pierwszeństwo starszemu i przeniósł je na siebie" $" 87$. Podobnie Ambroży Autpert odwołuje się do figury Ezawa i porównuje te społeczności, które i Augustyn konfrontuje w kontekście walki braci o pierworództwo. Szukający namiętnie pokarmu materialnego Ezaw symbolizuje Izraela, który zajęty przyjemnościami ziemskimi skłonił się ku temu, co cielesne. Nowy lud, którego siedzibą w Apokalipsie jest nowe Jeruzalem, zasłużył na to, by zająć pierwsze miejsce zamieszkania i spoczynku w domu Ojca i otrzymać na własność najlepszy dział na ziemi żyjących. Tymczasem „synowie królestwa”, czyli Żydzi, zgodnie z Łk 13,28-29, zostają wyrzuceni na zewnątrz w ciemność. W nawiązaniu do rozmowy Jezusa z Kananejką Ambroży stwierdza, że „szczenięta” zostają adoptowane na „synów królestwa”, a dotychczasowych „synów królestwa” czeka los odwrotny (por. Mt 15,27 par. $)^{88}$. Uczestnicząc we wspólnocie z Jakubem, jak i innymi patriarchami, Kościół ma wiele wspólnego z jego historią.

${ }^{83}$ Por. Grzegorz z Elwiry, Tractatus Origenis de libris Sanctarum Scripturarum, V, 37, dz. cyt., s. 43.

${ }^{84}$ Por. Prokop z Gazy, Commentarii in Octateuchum, in Gen. 27,45, PG 87/1, kol. 425; ta sama myśl: Cyryl Aleksandryjski, Glaphyra in Pentateuchum, in Gen., IV, 2, PG 69, kol. 184.

${ }^{85}$ Ireneusz z Lyonu Adversus haereses, IV, 8,1, dz. cyt., SCh 100, s. 467.

${ }^{86}$ Por. Prokop z Gazy, Commentarii in Octateuchum, in Gen. 27,45, PG 87/1, kol. 425.

${ }^{87}$ Augustyn z Hippony, Contra mendacium, 10, 24, ed. J. Zycha, Wien 1900, CSEL 41, s. 501.

${ }^{88}$ Por. Ambroży Autpert, Expositio in Apocalypsin, X, in 21,26, ed. R. Weber, Turnhout 1975, CCM 27A, s. 830. 
W centrum zapowiedzi Jezusa znajduje się uczta eschatologiczna w społeczności zbawionych. Ona też jest przedmiotem refleksji naszych komentatorów. Zwróćmy najpierw uwagę na typologię uczty niebieskiej, którą spotykamy w rozpatrywanej egzegezie. Pewne wydarzenia zarówno starotestamentalne, jak i w życiu ziemskim Jezusa, są wskazaniem na ucztę w królestwie Bożym. Piotr Chryzolog dostrzega w gościnnym przyjęciu przez Abrahama trzech tajemniczych gości (por. Rdz 18,1-8) zapowiedź tej gościnności, którą okaże kiedyś w niebie, przyjmując rzesze zbawionych do wspólnej uczty i społeczności ze sobą. Jednym z gości przy stole ziemskim u Abrahama był Bóg, a dwaj inni symbolizowali przyszłe ludy ze wschodu i zachodu, które zasiądą z Abrahamem przy stole niebieskim. Gościnność ziemska Abrahama, na pierwszym miejscu zwrócona ku Bogu, udoskonaliła go i uzdolniła do przewodniczenia uczcie w niebie ${ }^{89}$. Przenosząc się na grunt Ewangelii, Cyryl Aleksandryjski radzi przyjrzeć się ekonomii Bożej, która znajduje wyraz w różnych wydarzeniach relacjonowanych przez Ewangelie. Oto na przykład Jezus przebywa z Kananejczykami w Galilei, daje się zapraszać do ich domów,

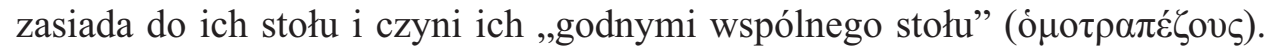
Za pomocą takich gestów wyraża akceptację dla nich. Niejako przyzwany do nich przez ich wiarę, wzywa i prowadzi ich do „niebieskiej komnaty”, do „Kościoła pierworodnych”, na ucztę razem ze świętymi, do udziału w boskim i duchowym święcie ${ }^{90}$. Chrystus już za życia zasiadał do stołu z poganami, z którymi zasiądzie w wieczności. Swoim czynem najlepiej wyjaśnił charakter złożonej obietnicy. Czasem typologia odsyła nie tyle do czasów ostatecznych, ile do innej rzeczywistości dokonującej się teraz, a znajdującej swoje spełnienie na końcu czasów. Jezus zapowiada w Mt 8,11, że głodni przybędą do stołu na ucztę pełną rozkoszy, jednak - zdaniem pewnego autora - zapowiedź tę poprzedza inna obietnica. Proroctwo Anny, matki Samuela, że „za chleb najmują się syci, a głodni już odpoczywają" (1 Sm 2,5), wolno odnieść do Żydów i pogan. Pierwsi mieli w Pismach pokarm wiary, czyli zapowiedź przyjścia Odkupiciela, ale nie skorzystali z niego, podczas gdy drudzy przyjmują tajemnice dotyczące Jego bóstwa i człowieczeństwa ku pokrzepieniu i osobistej radości ${ }^{91}$. Ambroży z Mediolanu widzi w rzeszy czterech tysięcy mężczyzn, „nie licząc kobiet i dzieci” (Mt 15,28), którą nakarmił Jezus rozmnażając chleby, figurę Kościoła, obecną także w Mt 8,11. Rzesza wiernych Kościoła, ze-

${ }^{89}$ Por. Piotr Chryzolog, Collectio sermonum, 42,6, ed. A. Olivar, Turnhout 1975, CCL 24, s. 239.

${ }^{90}$ Por. Cyryl Aleksandryjski, Commentarii in Joannem, ed. P.E. Pusey, Sancti patris nostri Cyrilli archiepiscopi Alexandrini in D. Joannis evangelium, t. 1, Oxford 1872, s. 208.

${ }^{91}$ Por. Grzegorz Wielki (?), In librum primum Regum expositionum libri VI, I, 99, ed. P. Verbraken, Turnhout 1963, CCL 144, s. 113. 
brana z czterech stron świata, otrzymuje więcej łaski aniżeli ci wykarmieni na pustkowiu ludzie ${ }^{92}$.

Nasi pisarze dostrzegają Chrystusa w centrum wydarzenia eschatologicznego, którym będzie uczta zbawionych. W jej kontekście pewien autor przywołuje inny obraz, mianowicie Syna Człowieczego, który przyjdzie jak błyskawica rozbłyskająca od wchodu do zachodu (por. Mt 24,27 par.) ${ }^{93}$. Mojżesz wyprowadził lud z niewoli egipskiej, a Chrystus wybawia ludzkość z całego kręgu ziemi, na którym się rozproszyła. To już dokonuje się częściowo, a w pełni dokona się zgodnie z Łk 13,28-29. Gdy zostanie zgromadzona mnogość pogan, Izrael dostąpi zbawienia ${ }^{94}$. Nie ulega wątpliwości, że chociaż Jezus zapowiada ucztę z patriarchami, to jednak On sam będzie głównym jej gospodarzem i uczestnikiem. W aluzji do Mt 8,11 Orygenes powiada, że na uczcie w królestwie będzie jadło się z drzewa życia i piło z prawdziwego szczepu winnego: „Albowiem «synowie Oblubieńca» nie mogą być pozbawieni tych pokarmów, nie mogą doznawać głodu, «dopóki Oblubieniec jest z nimi»" (Łk 5,34) ${ }^{95}$. W „królestwie Ojca” Chrystus będzie pił kielich nowy ze swoimi uczniami (por. Mt 26,29) ${ }^{96}$. Na Jego obecność w podobnym kontekście wskazuje Augustyn. On będzie zasiadał ze swoimi przy stole, co więcej, będzie im usługiwał (por. Łk 12,37). Ażeby tam przybyć, sam musiał dostąpić Paschy, czyli przejścia: wypełnił dzieła Boże, cierpiał, został ukrzyżowany, zmartwychwstał i udał się do Ojca ${ }^{97}$. Jezus będzie usługiwał przy stole, jako Dobry Pasterz będzie pasł. Pokarmem i napojem będzie sama Prawda. Pokarm ten będzie umacniał i nigdy go nie zabraknie ${ }^{98}$. Jak sądzi inny autor, Chrystus udzieli swoim błogosławieństwa w królestwie Boga, wstawiając się do Ojca i prosząc dla wszystkich o jedność oraz uświęcenie w prawdzie (por. J 17,17 $)^{99}$. Ludy zasiadające do uczty ,z Abrahamem, Izaakiem i Jakubem”, które zostały dane Chrystusowi od Boga „w dziedzictwo” (Ps 2,8), w Nim znajdą swój spoczynek. Teraz spełnia się obietnica właśnie przez to, że ludy

\footnotetext{
${ }^{92}$ Por. Ambroży z Mediolanu, Wykład Ewangelii według św. Lukasza, VI, 82n., tłum. W. Szołdrski, Warszawa 1977, PSP 16, s. 241n.

${ }_{93}$ Por. Liber questionum in evangeliis. De interpretatione nominum, ed. J. Rittmueller, Turnhout 2003, CCL 108F, s. 9.

${ }^{94}$ Por. Hieronim ze Strydonu, In Hieremiam prophetam, 4, ed. S. Reiter, Wien 1960, CSEL 74, s. 274.

${ }^{95}$ Por. Orygenes, Homilie o Księdze Rodzaju, XVI, 4, thum. S. Kalinkowski, Warszawa 1984, PSP 31/1, s. 151.

${ }^{96}$ Por. Beatus z Liebany, Commentarius in Apocalipsin, 10,3,2-14, dz. cyt., s. 589.

${ }^{97}$ Por. Augustyn z Hippony, Sermones, 103,5, PL 38, kol. 615; tamże, 179,6, kol. 969.

${ }^{98}$ Por. Augustyn z Hippony, Sermones, 104, w: Sancti Aurelii Augustini Sermones selecti duodeviginti, dz. cyt., s. 58; Augustyn z Hippony, Sermones, 362,29, PL 39, kol. 1633.

${ }_{99}$ Por. Prokop z Gazy, Commentarii in Octateuchum, in Gen. 27,45, PG 87/1, kol. 425; ta sama myśl: Cyryl Aleksandryjski, Glaphyra in Pentateuchum, in Gen., IV, 2, PG 69, kol. 184.
} 
ze wszystkich stron świata przyjmują wiarę w Chrystusa ${ }^{100}$. Kiedyś zasiądą do stołu, aby spożywać „chleb aniołów”, a Pan będzie im usługiwał ${ }^{101}$.

Beda Czcigodny we właściwy sobie wnikliwy sposób ubogaca „chrystocentryzm" uczty jeszcze jednym elementem. Jego zdaniem, jeśli obecność Chrystusa na uczcie jest darem, i to największym, to w ogóle cała uczta jest Jego darem. Uczta wespół z patriarchami w królestwie Bożym pozostaje pod kilkoma względami niezasłużoną łaską. Po pierwsze, łaską jest dostęp do niej, który mamy nie dzięki ofierze cierpliwie znoszonych utrapień czy dokonanych dzieł, ale dzięki Synowi Bożemu. On w tajemnicy swego pokornego i ubogiego przyjścia oraz Paschy pokonał śmierć i otworzył nam bramy królestwa, które nie były wcześniej otwarte. Po drugie, sama uczta będzie łaską, skoro sami z siebie nie jesteśmy w stanie zasiadać do stołu i odpoczywać w tym królestwie, ale dzięki Jego łasce, na co Jezus wskazał, mówiąc gdzie indziej, że On sam będzie usługiwał swoim sługom (por. Łk 12,37) ${ }^{102}$. Już Orygenes podkreślał, że wielu przybędzie do królestwa niebieskiego i zasiądzie do stołu z patriarchami „dzięki łasce Pana naszego Jezusa Chrystusa”"103.

Nasi autorzy wskazują na kilka innych dobrodziejstw owej uczty, poza obecnością Chrystusa. Mając Abrahama za ojca w wierze, narody będą razem z nim, przez wiarę w Chrystusa, uczestniczyć w królestwie Bożym we wszystkich dobrach Zbawcy ${ }^{104}$. Jak komentatorzy często podkreślają, tym dobrem jest odpoczynek. Euzebiusz z Cezarei stwierdza, może powtarzając za Orygenesem, że ludy zasiądą w królestwie Bożym, czyli doznają spoczynku ${ }^{105}$. Zasiadanie przy stole tym bardziej jest odpoczynkiem, skoro w kulturze starożytnej praktykowano biesiadowanie na sofie w pozycji półleżącej. Rozumiejąc Mt 8,11 w tym sensie, że głodni przybędą do stołu na ucztę eschatologiczną pełną rozkoszy, jeden z autorów używa na określenie tego miejsca słowa recubitus $^{106}$ zawierającego ową dwuznaczność. Oznacza bowiem zarówno miejsce przy stole jadalnym, jak i leżenie, odpoczywanie. Dodajmy, że tę samą dwu-

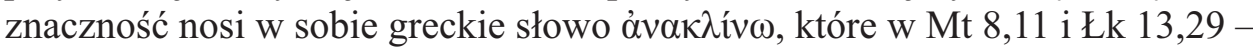
użyte w stronie biernej - oznacza 'położyć się'. Skądinąd, kontekst uczty każe polskim tłumaczom wyrazić je na ogół przez 'zasiąść do stołu'. To samo sło-

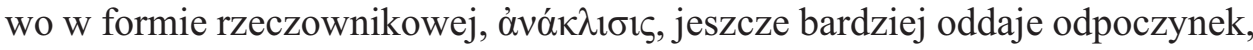
znacząc 'leżenie', 'opieranie się na wezgłowiu'.

${ }^{100}$ Por. Kasjodor, Expositio sancti Pauli Epistulae ad Romanos, 4, PL 68, kol. 435.

${ }^{101}$ Por. Epifaniusz Łaciński, Interpretatio Evangeliorum, 52, dz. cyt., s. 133.

102 Por. Beda Czcigodny, In primam partem Samuhelis libri IV. Nomina locorum, III, in 16, 11, ed. D. Hurst, Turnhout 1962, CCL 119, s. 140.

${ }^{103}$ Orygenes, Homilie o Księdze Jozuego, XXV, 4, dz. cyt., s. 133.

104 Por. Cyryl Aleksandryjski, Commentarii in Joannem, ed. P.E. Pusey, t. 2, Oxford 1872, s. 130.

105 Por. Euzebiusz z Cezarei, Fragmenta varia, in Luc. 12, 36, PG 24, kol. 561.

${ }^{106}$ Grzegorz Wielki (?), In librum primum Regum expositionum libri VI, I, 99, dz. cyt., s. 113. 
Również Augustyn chętnie powtarza w kontekście Mt 8,11 par., że zasiadać przy stole, to doznawać spokoju, odpoczynku ${ }^{107}$. Walor spoczynku akcentuje jeszcze bardziej inny obraz użyty w Ewangelii dla wyrażenia szczęścia zbawienia, mianowicie „łono Abrahama”. W naszej analizie nie zagłębiamy się w interpretację patrystyczną tej semickiej metafory. Faktem jest, że niektórzy pisarze - może przez swobodę w cytowaniu Ewangelii i pokrewieństwo pojęć, a może determinowani wariantem używanego tekstu Ewangelii - mieszają spoczynek Łazarza na łonie Abrahama w Łk 16,22-23 z zasiadaniem z nim do stołu w Łk 13,29 i Mt 8,11. Euzebiusz z Cezarei - w duchu ariańskim? - sądzi, że przebywanie „,na łonie” Abrahama, Izaaka i Jakuba nie oznacza bycia tym samym, co oni, lecz bycie pod ich troską - podobnie jak Syn, będąc przed wiekami „na łonie” Ojca, nie był tym samym, kim był Oj$\operatorname{ciec}^{108}$. Dla Augustyna łonem Abrahama jest „wieczny odpoczynek na ustroniu u wielkiego Ojca; łono bowiem oznacza ustronie [secretum], na którym odpoczywa utrudzony"109. W poglądzie tym są zależni od Augustyna Grzegorz Wielki i Beda Czcigodny. Jednak to dopiero Grzegorz utożsamia wspólnotę stołu z Abrahamem w Mt 8,11 par. z przebywaniem na łonie Abrahama przez zmarłego nędzarza w przypowieści o bogaczu i Łazarzu. Łono Abrahamowe jest znakiem „ustronnego odpoczynku u Ojca?” [secreta requies Patris $]^{110}$. To samo powtarza Beda Czcigodny ${ }^{111}$. Podobnie Grzegorz Wielki i Beda Czcigodny tłumaczą zasiadanie przy wspólnym stole. Zasiąść przy stole, to doznać wiecznego pokrzepienia. Zasiadanie to odpoczynek w królestwie ${ }^{112}$.

Ojcowie wskazują na radość i szczęście oraz inne dobra będące udziałem biesiadników przy wspólnym stole z Abrahamem, Izaakiem i Jakubem. Wielkość tego szczęścia uwyraźnia Jan Chryzostom w kontraście do kary czekającej według Mt 8,12 tych, którzy odrzucili wezwanie Boga:

Niechaj nikt nie sądzi, że to tylko jedna groźba, gdyż zarówno kara dla jednych, jak i radość dla drugich, jest podwójna. Kara dla pierwszych nie tyle dlatego, że

${ }^{107}$ Por. Augustyn z Hippony, Sermones, 103,5, PL 38, kol. 615; tamże, 77,9, kol. 489; Augustyn z Hippony, Sermones, 104, w: Sancti Aurelii Augustini Sermones selecti duodeviginti, dz. cyt., s. 58.

108 Por. Euzebiusz z Cezarei, De ecclesiastica theologia, I, 20, ed. E. Klostermann, G.C. Hansen, Leipzig-Berlin 1972, GCS $14^{2}$, s. 83.

${ }^{109}$ Augustyn z Hippony, Sermones, 113B, „Miscellanea Agostina”, t. 1, Roma 1930-1931, s. 290.

${ }^{110}$ Grzegorz Wielki, Homiliae in evangelia, 40,2, ed. R. Etaix, Turnhout 1999, CCL 141, s. 396. W polskim przekładzie błędnie przetłumaczono na „ustronny odpoczynek ojców” zamiast „ustronny odpoczynek u Ojca" (Grzegorz Wielki, Homilie na Ewangelie, I, 40,2, b. thum., Warszawa 1998, s. 414).

${ }_{111}$ Por. Beda Czcigodny, In Lucae evangelium expositio, V, in 16,31, ed. D. Hurst, Turnhout 1960, CCL 120, s. 306.

112 Por. Grzegorz Wielki, Homilie na Ewangelie, I, 13, 4, dz. cyt., s. 108; to samo Beda Czcigodny, In Lucae evangelium expositio, IV, in 12,37, dz. cyt., s. 257. 
utracili, lecz że utracili swoją własność; radość zaś dla drugich nie tyle dlatego, że osiągnęli, lecz że osiągnęli to, czego się nie spodziewali; oprócz tego trzecia radość, że otrzymali to, co należało do tamtych. Synami królestwa nazywa tu tych, dla których królestwo zostało przygotowane, co najbardziej ich dotykało. Pokazawszy na podstawie obietnic i przyrzeczenia, że są na łonie [Abrahama], następnie ich wyklucza ${ }^{113}$.

Ktoś inny kojarzy słowa w Mt 8,11 z zapowiedzią w Mt 26,29 nowej uczty ze swoimi uczniami. Pić „nowy kielich” oznacza przygotowanie nowych ciał przy zmartwychwstaniu, nową radość, uczciwą zapłatę sprawiedliwości za prawdziwą wiarę ${ }^{114}$. Tak więc udział w królestwie Bożym razem ze sprawiedliwymi nie będzie polegał tylko na wewnętrznym doświadczeniu wspólnoty, szczęścia, ale przeobrazi ontologicznie ludzką egzystencję, przynosząc jej nieśmiertelność pod względem także cielesnym.

Co do doświadczenia szczęścia i przyjemności w królestwie Boga, to Augustyn poucza, że nie powinniśmy wyobrażać uczty wespół z patriarchami jako źródła cielesnych przyjemności. Mamy powstrzymywać się od pożądania czegokolwiek takiego w owym królestwie. Trwanie w przyziemnych wyobrażeniach prowadziłoby w konsekwencji do tego, że zamiast dążyć do zamiany wad na cnoty, opieralibyśmy nasze życie dalej na wadach.

Co innego jest pragnąć królestwa niebieskiego ze względu na mądrość i życie wieczne, a co innego pragnąć go ze względu na pomyślność ziemską, żebyśmy po tamtej stronie doznawali jej w stopniu obfitszym i większym. Jeśli spodziewasz się, że będziesz bogaty w owym królestwie, to nie wyzbywasz się pożądliwości, lecz zmieniasz [jej przedmiot]. A jednak będziesz tam bogaty, i to jedynie tam będziesz bogaty ${ }^{115}$.

W tym duchu wypowiada się Ambroży z Mediolanu, stwierdzając, że przychodzący do królestwa będą rozkoszować się wiecznym pokojem, gdy umrą dla zwierzęcych poruszeń ${ }^{116}$.

W powyższej wypowiedzi Augustyn podkreśla mądrość będącą udziałem zbawionych. Wszystkie władze natury ludzkiej doznają nasycenia. Pod względem uczuciowym człowiek nakarmi się przyjemnością, szczęściem, natomiast pod względem umysłowym - prawdą, mądrością. Tę myśl można uznać za

${ }^{113}$ Jan Chryzostom, Homilie na Ewangelię według św. Mateusza, XXVI, 4, dz. cyt., s. 321n.

114 Por. Apringiusz z Civitas Pacensis, Tractatus in Apocalypsin fragmenta quae supersunt, 6,19,9, ed. R. Gryson, Turnhout 2003, CCL 107, s. 72; Beatus z Liebany, Commentarius in Apocalipsin, 10, 3, 2-14, dz. cyt., s. 589.

${ }^{115}$ Augustyn z Hippony, Sermones, 77,9, PL 38, kol. 489.

${ }^{116}$ Por. Ambroży z Mediolanu, De excessu fratris Satyri, 2,101, dz. cyt., s. 305. 
charakterystyczną dla biskupa Hippony. W jednej z mów stwierdza, że chrześcijanie dopuszczeni do społeczności wiary razem z Abrahamem, Izaakiem i Jakubem będą karmić się sprawiedliwością i mądrością ${ }^{117}$. Wyjaśniając w innej mowie, że ucztą zapowiadaną w Mt 8,11 par. jest nagroda dla świętych w Jego królestwie, pyta: Jakim pokarmem będzie nas karmił Zbawiciel? Cząstka, którą wybrała Maria (por. Łk 10,42), będzie wzrastać w tamtej rzeczywistości, a nie umniejszać się. Będzie tam uczta, to znaczy serce człowieka, wierne i święte, będzie radować się światłem prawdy, obfitością mądrości ${ }^{118}$. W jeszcze innej mowie powiada Augustyn, że zaproszeni nie będą ucztować „,z Platonem czy Cyceronem, ale z Abrahamem, Izaakiem i Jakubem w królestwie Boga". Tymczasem Izraelici, chociaż byli synami, nie chcieli, aby Syn Boży rządził nimi, dlatego zostaną wyrzuceni w ciemności zewnętrzne ${ }^{119}$. Autor polemizuje zarówno z filozofią pogańską, jak i postawą żydowską. Ani w tym życiu, ani w przyszłym chrześcijanie nie szukają mądrości tego świata, ale mądrości wiecznej, którą będą dzielić z podobnymi sobie.

\section{Pareneza obietnicy}

Wizja zaszczytnej uczty w królestwie Bożym zakłada wolny wybór zaproszonych. Jeśli wielu przybędzie na nią, to po przebyciu pewnej duchowej drogi. Nie brakuje u naszych komentatorów zastanowienia się nad postawą człowieka odpowiadającego na zaproszenie Boga. Refleksja ta przechodzi często $\mathrm{z}$ komentarza $\mathrm{w}$ parenezę.

Alternatywa wyboru - za lub przeciw - stwarza pewien dramatyzm. Za ostateczny kształt tego wyboru odpowiada sam człowiek. Powiada Justyn Męczennik, że Bóg „nie jest odpowiedzialny, nawet jeśli już wie, że staną się niesprawiedliwi, zarówno aniołowie, jak i ludzie, że będą niegodziwi, ale każdy jest odpowiedzialny za samego siebie, jakim będzie" ${ }^{20}$. Z jednej strony pozostaje pewne, że ,spoczywają w królestwie Boga z Abrahamem, Izaakiem i Jakubem, ponieważ nie wymawiali się, gdy zaproszono ich na ucztę" $(\text { Łk } 14,78)^{121}$. Z drugiej strony zbawienie człowieka nie przychodzi samoczynnie. O ile prawdą jest, jak zapowiada Jezus, że wielu zasiądzie do jednego stołu z patriarchami, pochodząc z różnych stron świata, o tyle też prawdą po-

${ }^{117}$ Por. Augustyn z Hippony, Sermones, 62,3, PL 38, kol. 417.

${ }^{118}$ Por. tamże, 179,6, kol. 969.

119 Por. Augustyn z Hippony, Sermo de passione Domini (218 auctus), 7, ed. R. Etaix, „Augustinianum" 34 (1994), s. 366.

${ }^{120}$ Justyn Męczennik, Dialog z Żydem Tryfonem, 140,4, dz. cyt., s. 316n.

${ }^{121}$ Por. Ambroży z Mediolanu, O dobrach przynoszonych przez śmierć, 12,53, thum. W. Szołdrski, Warszawa 1971, PSP 7, s. 165. 
zostaje, zdaniem Pseudo-Hipolita, że w dniach ostatecznych znajdzie się wielu, którzy, przybywając „ze wschodu i zachodu, z północy i południa”, będą bezskutecznie pytać, skąd przybędzie i gdzie jest Chrystus. Będą szukać Jego imienia, jednak w swoim błędnym myśleniu nie rozpoznają $\mathrm{Go}^{122}$. Uczniowie Chrystusa nie mają pewności zbawienia, skoro wybór człowieka jest kruchy. Odrzucenie przytrafiło się

nie tylko Żydom, lecz również tym, którzy uwierzyli. Judasz był przecież synem królestwa i usłyszał razem z uczniami: „Będziecie siedzieć na dwunastu tronach” (Mt 19,28), a stał się synem piekła; Etiopczyk zaś, który był barbarzyńcą, został jednym z tych, którzy przyszli ze wschodu i zachodu słońca oraz którzy będą uwieńczeni z Abrahamem, Izaakiem i Jakubem (por. Dz 8,27-38). Dzieje się to również teraz. „Wielu pierwszych będzie ostatnimi”, powiada, „a ostatnich pierwszymi” (Mt 19,30). A mówi to, aby ci nie upadali tak, jakby już nie mogli się podnieść, a tamci nie ufali, że już mocno stoją ${ }^{123}$.

Chociaż ci, „którzy urządzają swe życie po przyjściu Chrystusa”, znajdują się pod pewnym względem w lepszej sytuacji niż inni przedtem, „bo otrzymali oni większą moc", to pod innym względem stoi przed nimi trudniejsze zadanie, bo „są zobowiązani do większych walk”124. Mając na uwadze „płacz i zgrzytanie zębów" (Mt 8,12) ze strony odrzuconych, Efrem Syryjczyk wyraża obawę: „Boję się, umiłowani, aby słowo Pana nie wypełniło się na nas $[\ldots]^{\prime 125}$. Jak stwierdza Cyprian z Kartaginy, potrzeba wiele modlitwy, aby nie odpaść od królestwa Bożego. „Żydzi przedtem byli synami Królestwa, kiedy to wiernie trwali jako synowie Boży. Później jednak, kiedy przestali Boga nazywać Ojcem, stracili i Królestwo. Stąd to my, chrześcijanie, którzy zaczynamy w modlitwie nazywać Boga Ojcem, prosimy też o to, żeby Królestwo Boga do nas przyszło"126.

Boży plan ratunku człowieka w kontekście ludzkiej wolności wyraża Pawłowy obraz zaszczepionej oliwki (por. Rz 11,17-24). Do tego obrazu często nawiązuje Augustyn. Bóg „świętych patriarchów, z których wyrósł lud Boży, zasadził niczym jakieś drzewo oliwne i udzielił mu błogosławieństwa". W tym drzewie oliwnym, w którego żywym pniu żyją patriarchowie, została złama-

122 Por. Pseudo-Hipolit Rzymski, De consummatione mundi, 9, ed. H. Achelis, Leipzig-Berlin 1897, GCS 1/2, s. 292.

${ }^{123}$ Jan Chryzostom, Homilie na Ewangelię wedlug św. Mateusza, XXVI, 5, dz. cyt., s. 322n.

${ }^{124}$ Tamże, XVI,4, s. 199.

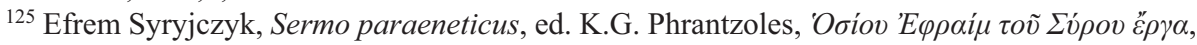
t. 1, Thessalonica 1995, s. 411; Efrem Syryjczyk, In secundum adventum domini nostri Jesu Christi, tamże, t. 3, 1990, s. 414; Efrem Syryjczyk, De patientia, tamże, t. 3, s. 322.

${ }^{126}$ Cyprian z Kartaginy, O Modlitwie Pańskiej, 13, tłum. W. Kania, w: Odpowiedź na Slowo, wstęp i oprac. H. Pietras, Kraków 1993, s. 73. 
na - za surowym, choć sprawiedliwym wyrokiem boskim - pycha i niewiara naturalnych gałęzi ${ }^{127}$. Tymi ,gałęziami pysznymi” stał się naród żydowski ${ }^{128}$. Tak oto zostanie wycięta naturalna gałąź, to jest dzieci królestwa zostaną wyrzucone precz, w ciemności, na skutek swojej niewiary, pychy, bezbożności i ignorancji. Nie będą już mogły powoływać się na pochodzenie od Abrahama ${ }^{129}$. W związku ze sprzeniewierzeniem się części tego ludu,

to drzewo oliwne zostało oczyszczone, a nie ścięte [...]. Pozostały wszakże gałęzie zdrowe i pożyteczne, bo właśnie stamtąd są Apostołowie. A skoro zostawione zostały gałęzie pożyteczne, to dzięki miłosierdziu Bożemu została tam wszczepiona dziczka pogan. [...] To jest właśnie to jedno drzewo przynależące do Abrahama, Izaaka i Jakuba. A co więcej, bliższym stała się dziczka Abrahamowi, Izaakowi i Jakubowi niż odłamane gałęzie ${ }^{130}$.

Jak stwierdza św. Paweł, zaszczepiona dziczka zaczęła uczestniczyć w żyzności oliwki (por. Rz 11,17) ${ }^{131}$. Pień miał taką wartość i żywotność, „że wszczepioną dziczkę oliwną mógł zamienić w siebie, podczas gdy dziczka nie mogła zmienić oliwce nazwy" ${ }^{132}$. Tak właśnie poganie niczym dziczka zasłużyli przez swoją pokorę na wszczepienie w drzewo oliwne - po to, by wbrew naturze przynosić owoc właściwy oliwce, czyli oliwę; zasłużyli, by łaska zmieniła ich naturę ${ }^{133}$. Stali się więc częścią tego duchowego drzewa, chociaż cieleśnie nie byli potomstwem Abrahama ${ }^{134}$. Ich przykładem są magowie przychodzący ze Wschodu, którzy nie szukali i nie adorowali w Jezusie króla pogan, ale króla Żydów. Czynili tak dlatego, że to szczep zostaje przyłączony do oliwki, zgodnie z Rz 11,24, a nie oliwka do szczepu ${ }^{135}$. Pokora i wiara pogan będzie kontrastować z postawą synów Starego Przymierza ${ }^{136}$. Odłamane

${ }^{127}$ Por. Augustyn z Hippony, Adversus Iudaeos, 1, PL 42, kol. 5.

${ }_{128}$ Por. tenże, Objaśnienia Psalmów, 134,7, tłum. J. Sulowski, Warszawa 1986, PSP 42/1, s. 121

${ }_{129}$ Por. Augustyn z Hippony, Epistulae, 140, 20, ed. A. Goldbacher, Wien 1904, CSEL 44, s. 197; Augustyn z Hippony, Sermones, 77,10, PL 38, kol. 489n.; tenże, Sermones, 342,4, PL 39, kol. 1503n.; tenże, Objaśnienia Psalmów, 134,7, dz. cyt., PSP 42/1, s. 122.

${ }^{130}$ Tenże, Objaśnienia Psalmów, 134,7, dz. cyt., PSP 42/1, s. 121.

131 Tamże.

132 Tenże, Sermo de passione Domini (218 auctus), 7, ed. R. Etaix, „Augustinianum” 34 (1994), s. 366.

${ }^{133}$ Por. Augustyn z Hippony, Sermones, 203,3, PL 38, kol. 1036; powtarza wypowiedź Augustyna: Cezary z Arles, Sermones Caesarii uel ex aliis fontibus hausti, 195,3, ed. G. Morin, Turnhout 1953, CCL 104, s. 790n.

${ }^{134}$ Por. Augustyn z Hippony, Objaśnienia Psalmów, 134,7, dz. cyt., PSP 42/1, s. 121 n.

${ }^{135}$ Por. tenże, Sermones, 201,2, PL 38, kol. 1031.

${ }^{136}$ Por. tenże, Epistulae, 140,20, dz. cyt., s. 197; tamże, 140,22, s. 200; tenże, Sermones, 77,10, PL 38, kol. 489n.; tenże, Sermones, 342,4, PL 39, kol. 1503n.; tenże, Adversus Iudaeos, 1, PL 42, kol. 51 . 
gałęzie Żydów „skutkiem odłamania już tam nie tkwią. Dziczka tam nie była, a jest. Oni swoją pychą zasłużyli na odłamanie", a nawracający się poganin „przez pokorę zasłużył na wszczepienie. Oni utracili korzeń, lud pogański się przy nim utrzymał". Augustyn przestrzega swoich wiernych, aby nie wynosili się ,ponad gałęzie”. Mają pamiętać, że to nie oni dźwigają korzeń, ale korzeń ich (por. Rz 11,17-18). Skoro usłyszeli „o Izraelu należącym do Boga”, nie powinni wyobcowywać się od niego. Biskup Hippony zwraca się do swego ludu: „Wszyscy zatem błogosławieni bądźmy w Bogu Abrahama, Izaaka i Jakuba" $" 137$.

Niezależnie od metafory zaszczepionego drzewa oliwnego nasi ojcowie kreślą obraz nawrócenia pogan, bogactwa ich wiary, na tle wyjałowienia duchowego Izraelitów. Ci pierwsi już teraz przystępują do królestwa Bożego, ci drudzy odstępują. Żyjący w czasach Konstantyna Wielkiego Euzebiusz z Cezarei stwierdza, że znaki królestwa Bożego dają się spostrzec po Kościołach Chrystusowych na całym świecie u wszystkich narodów. Wielu ludzi będzie żyło zgodnie z Ewangelią, naśladując proroków oraz patriarchów, Abrahama, Izaaka i Jakuba. Odrzucą wielobóstwo odziedziczone od przodków, a przyjmą poznanie Boga, Pana wszechrzeczy. Wielu pogan godnych tej samej czci, skoro zaczęli prowadzić podobny styl życia, przystąpi do wspólnoty z Abrahamem. Przez swoich praojców zostaną nazwani ich potomkami i spadkobiercami, synami królestwa. Podobna jak u tamtych będzie w nich moc i będą mieć podobny udział w królestwie Bożym. Natomiast ci, którzy odstąpili od rzeczy obiecanych, będą świadkami spustoszonej stolicy, zdobycia ich świątyni, zostaną rozproszeni pośród wszystkich ludów, stając się ich sługami, ustanie kult przepisany ich prawem, nie poznają Chrystusa, odrzucą naukę ewangeliczną ${ }^{138}$. Nawet z daleka nie będą mogli zobaczyć swojej ojczyzny; nie będą mieli jak dawniej proroków i objawienia; nie doznają Bożej pomocy, nie zobaczą Bożego dzieła ${ }^{139}$. Podobnie zauważa Bazyli z Seleucji, że mieszkańcy ziemi odrzucają wielobóstwo, które wykluczało kult Boga Jedynego, oraz diabelskie przesądy, a powołują się na Abrahama. Wyrzekając się swoich naturalnych ojców, przyjmują ojców nadprzyrodzonych. Kościół pogan wchodzi przez wiarę w dziedzictwo wybranego narodu i swoimi czynami potwierdza prawdziwość obietnicy Chrystusa ${ }^{140}$.

W postawie człowieka otwierającej dostęp do duchowych dóbr przygotowanych przez Boga na pierwszy plan wysuwa się wiara. Nawrócone narody pogańskie zasłużyły dzięki swojej wierze i pobożności na udział w społecz-

\footnotetext{
${ }^{137}$ Augustyn z Hippony, Objaśnienia Psalmów, 134,7, dz. cyt., PSP 42/1, s. 121.

${ }^{138}$ Por. Euzebiusz z Cezarei, Fragmenta varia, in Luc. 13,21, PG 24, kol. 569.

${ }^{139}$ Por. tenże, Theophania, IV, III, dz. cyt., s. 168n.; tenże, De ecclesiastica theologia, I, 20,

${ }^{140}$ Por. Bazyli z Seleucji, Sermones, 19, 2, PG 85, kol. 244.
} dz. cyt., s. 83 . 
ności świętych ${ }^{141}$. „Albowiem ze wschodu i z zachodu, z południa i północy przybywają, odpoczywają razem z patriarchami, wyrzuciwszy tych, którzy cieleśnie od nich pochodzili, ale ich wiary nie naśladowali" ${ }^{\prime 12}$. W królestwie Bożym

będą odpoczywać narody z całego świata wraz z Abrahamem, Izaakiem i Jakubem; nie ze względu na co innego, jak dlatego, że zachowali wiarę Abrahama, Izaaka i Jakuba. Dlatego też i Apostoł powiedział: „Stąd Pismo widząc, że w przyszłości Bóg na podstawie wiary będzie dawał poganom usprawiedliwienie, już Abrahamowi oznajmił tę radosną nowinę: $\mathrm{W}$ potomstwie twoim będę błogosławione wszystkie narody" (Ga 3,8), żeby mianowicie ci byli błogosławieni w potomstwie Abrahama, którzy będą naśladowali wiarę Abrahama ${ }^{143}$.

Obietnica Jezusa w Mt 8,11 pada w kontekście chwalonej przez Niego wiary setnika. Na tle wiary pogan, takich jak setnika, Orygenes powiada: „o ile wyżsi są poganie, gdy chodzi o wiarę"144. Jak sądzi Epifaniusz Łaciński, chociaż Bóg przez tysiące lat działał tyle znaków i cudów w Izraelu, chociaż znosił cierpliwie grzechy swego ludu, nigdy nie spotkał takiej wiary jak teraz po całej ziemi wśród ludów pogańskich, mimo że nie są świadkami podobnych cudów i znaków. Wszystkie ludy po całym świecie, które uwierzyły w Chrystusa, przyjdą ,ze wschodu i z zachodu i zasiądą do stołu z Abrahamem, Izaakiem i Jakubem w królestwie niebieskim”, przynosząc „owoce sprawiedliwości i świętości”145. Epifaniusz łączy słowa Jezusa w Mt 8,11 z innymi Jego słowami - o objawieniu tajemnic Bożych ,prostaczkom”. Im właśnie objawia je, aby „szukali dóbr raju i dóbr przyszłych królestwa niebieskiego”. To właśnie pogan utrudzonych niewolą diabła i obciążonych grzechami, nawracających się przez wiarę i porzucenie zła, „pokrzepia” Chrystus (por. Mt 11,25-30 par.). „Pokrzepił” bowiem wszystkich wierzących w Niego „przez wiarę, sprawiedliwość, świętość i życie wieczne" ${ }^{146}$. Jak stwierdza Beda Czcigodny, wiara została poczytana setnikowi za sprawiedliwość, podobnie jak wcześniej Abrahamowi (por. Ga 3,6). „Poczytana za sprawiedliwość nie zostaje wiara opieszała i sama tylko jedna, ale taka, która pobudza do działania przez miłość. Poczytana zostaje [za sprawiedliwość] również taka, która nawet nie ma już czasu na działanie, mając jednak doskonałą wolę działania”. Taką wiarą

\footnotetext{
${ }^{141}$ Por. Chromacjusz z Akwilei, Tractatus in Mathaeum, 39, 2, dz. cyt., s. 383n.

${ }^{142}$ Augustyn z Hippony, Objaśnienia Psalmów, 68,1, dz. cyt., PSP 38, s. 191.

143 Tenże, Przeciw Faustusowi [księgi I-XXI], 16,24, tłum. J. Sulowski, Warszawa 1991, PSP

${ }^{144}$ Orygenes, Komentarz do Listu św. Pawła do Rzymian, II, 14, dz. cyt., s. 135.

${ }^{145}$ Epifaniusz Łaciński, Interpretatio Evangeliorum, 22, dz. cyt., s. $31 \mathrm{n}$.

146 Tamże, 26, s. 42.
} 55 , s. 166n. 
wykazał się dobry łotr (por. Łk 23,40-43). Również poczytano za sprawiedliwość wiarę setnika i jego rodziny, który otrzymał dar Ducha Świętego jeszcze przed chrztem (por. Dz 10). „Ledwie została poczęta w sercu, a już była gotowa do działania przez miłość"147.

Augustyn także zatrzymuje się nad fenomenem postawy setnika. Za jej istotę uznaje wiarę w łączności z pokorą. W kontekście wiary rzymskiego dowódcy Augustyn stwierdza, że owi ludzie „ze wschodu i zachodu” przybędą przez wiarę, bowiem: „przybyć jest tym samym co uwierzyć”. Wiara jest przybyciem, apostazja - odejściem ${ }^{148}$.

Ów setnik bowiem nie pochodził z narodu żydowskiego. Albowiem wśród ludu żydowskiego pyszni odtrącali od siebie Boga. Pośród książąt pogańskich znalazł się pokorny, który do siebie zaprosił Boga. Jezus podziwiając jego wiarę, zganił niewierność Żydów. Wydawało im się, że są zdrowi, gdy tymczasem niebezpiecznie chorowali, kiedy nie rozpoznając Lekarza, zabili go ${ }^{149}$.

Pewien rodzaj mocy sprawił, że człowiek wywołał niechęć do siebie, aby słabością był strofowany. Wszak przez pychę spowodował niechęć po to, aby przez pokorę został poprawiony. Wszyscy pyszałkowie mówią, że są mocni. Dlatego zwyciężyło wielu przychodząc ze wschodu i z zachodu, i odpoczywają w królestwie niebieskim z Abrahamem, Izaakiem i Jakubem. Dlaczego zwyciężyli? Ponieważ nie chcieli być mocnymi. [...] Obawiali się zaufać sobie. Nie ustanawiali własnej sprawiedliwości, chcąc się poddać sprawiedliwości Bożej. [...] Wspomnijcie na wiarę owego centuriona, poganina $\mathrm{z}$ pochodzenia, tak bardzo w sobie słabego, tak nie mocnego, że powiedział: „Nie jestem godzien, abyś wszedł pod mój dach”. [...] Chrystus zwracając uwagę na te słowa centuriona, powiedział do idących za sobą: „Zaprawdę powiadam mam, nie znalazłem takiej wiary w Izraelu”. Spotkał tak słabego, podczas gdy Izraelici byli mocni ${ }^{150}$.

Biskup Hippony widzi w postawie setnika wielki walor pedagogiczny i dlatego w dłuższym wywodzie kaznodziejskim stawia go za wzór swoim słuchaczom.

Wiarę warunkującą dostęp do wspólnoty z patriarchami wiążą nasi autorzy $\mathrm{z}$ innymi cnotami. Augustyn łączy ją z miłością:

147 Beda Czcigodny, In principium Genesis usque ad nativitatem Isaac, IV, 15,5-6, ed. C.W. Jones, Turnhout 1967, CCL 118A, s. 195n.

148 Augustyn z Hippony, Sermones, 62A, „Miscellanea Agostina”, t. 1, Roma 1930-1931, s. 609.

149 Tenże, Objaśnienia Psalmów, 46,12, dz. cyt., PSP 38, s. 204; por. tenże, Objaśnienia Psalmów, 134,7, dz. cyt., PSP 42/1, s. 122; tenże, Epistulae, 140,20, dz. cyt., s. 197; tamże, 140,22, s. 200.

${ }^{150}$ Augustyn z Hippony, Objaśnienia Psalmów, 38,18, dz. cyt., PSP 38, s. 79. 
Oto wiara, która działa przez miłość. Ona to prosząc, szukając, pukając, wyprasza ducha dobrego, dzięki któremu sama miłość rozlana jest w sercach naszych. Bo ktokolwiek kieruje się tym Duchem Bożym, ten jest dzieckiem Boga. Tacy zostają przyjęci i odpoczywają z Abrahamem, Izaakiem i Jakubem w królestwie niebieskim, po wypędzeniu sługi, który nie zamieszkuje w domu na wieki $(\mathrm{J} 8,35)^{151}$.

Doctor caritatis nie ujmuje miłości jako jednej z cnót, ale jako nadprzyrodzoną dyspozycję czyniącą z nas dzieci Boże, a przez to i - potomstwo Abrahamowe. W jakiś sposób już teraz taki człowiek dzieli wspólnotę z Abrahamem. Otwiera się więc cały obszar parenezy domagającej się różnych cnót i postaw niezbędnych do spełnienia się obietnicy zapowiadanej przez Jezusa. Ambroży łączy wiarę z pobożnością, gdy stwierdza, że przychodzący do królestwa Bożego poganie kiedyś trwali w złości (,„perfidia”), teraz w wierze i pobożności ${ }^{152}$.

Epifaniusz Łaciński podkreśla, że wspólnota ,z Abrahamem, Izaakiem i Jakubem” nie jest tylko docelowym etapem naszej wędrówki wiary. Mając „iść śladami świętych, zachęceni boskim autorytetem", możemy już teraz w jakiś sposób uczestniczyć w ich życiu. Wskazuje konkretnie na posłuszeństwo Bogu, które warunkuje udział w Jego życiu. Do królestwa Bożego wchodzi ten, kto pełni wolę Ojca (por. Mt 12,50 par.) ${ }^{153}$. Postulując także wytrwałość, stwierdza, że ci, którzy wytrwali przy Chrystusie w przeciwnościach, odziedziczą królestwo i będą w Nim jedli i pili przy Jego stole (por. Łk 22,28-29), a On sam

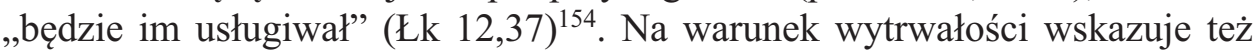
Augustyn. Poganie dostąpią udziału w tej uczcie, jeśli wytrwają w dobru ${ }^{155}$.

Metody z Olimpu postuluje czujność i wstrzemięźliwość, wiążąc zapowiedź uczty we wspólnocie z patriarchami z przypowieścią o sługach czuwających na przyjście pana (por. Łk 12,35-38). „Wypada więc, byśmy zapalili w sercach niegasnące światło wiary i opasawszy biodra powściągliwością wciąż czuwali i oczekiwali Pana, ażeby on, gdyby zechciał nas zabrać w pierwszym albo drugim czy trzecim okresie, znalazł nas przygotowanych i wypełniających jego nakaz oraz umieścił nas w łonie Abrahama, Izaaka i Jakuba”. Trzy straże nocne oznaczają „trzy etapy naszego życia: młodzieńczy, dojrzały i starczy”"156.

Grzegorz z Nyssy zwraca uwagę na dobre czyny chrześcijanina, przez które ma udział we wspólnocie z Abrahamem: „Prawdziwy Izraelita, syn

${ }^{151}$ Tenże, Objaśnienia Psalmów, 118,22,1, dz. cyt., PSP 41, s. 297n.

152 Por. Ambroży z Mediolanu, Expositio psalmi CXVIII, 12, 23, ed. M. Petschenig, Wien 1913, CSEL 62, s. 264.

${ }^{153}$ Por. Epifaniusz Łaciński, Interpretatio Evangeliorum, 35, dz. cyt., s. 73.

${ }^{154}$ Por. tamże, 52, s. 133.

${ }^{155}$ Por. Augustyn z Hippony, Adversus Iudaeos, 1, PL 42, kol. 5.

${ }^{156}$ Metody z Olimpu, Uczta, V, 3, thum. S. Kalinkowski, Warszawa 1980, PSP 24, s. 57n. 
Abrahama, ku niemu zwraca się w życiu, aby poprzez swoje dobre uczynki znaleźć się wśród rodziny wybranych, uwolnionych od kary pieca"157. Do podobnego wniosku dochodzi Pseudo-Klemens, zestawiając Łk 13,28 ze słowami w Mt 22,14 o wielu powołanych, a małej liczbie wybranych. To, że wielu zostało powołanych i przyszło, nie jest jeszcze powodem do nagrody, gdyż do Boga należy tak poruszyć człowieka, aby - będąc powołany - przyszedł. Tymczasem do człowieka należy w konsekwencji powołania czynić dobro - i za to zostanie wynagrodzony. W tym sensie autor sugeruje, że „wybranymi” są ci, których Bóg nagrodzi za czynione dobro ${ }^{158}$.

\section{Podsumowanie}

Zestawiając Augustyńską wykładnię Mt 8,11 i Łk 13,28-29 z wykładnią innych ojców, dostrzegamy u niego z jednej strony pewną syntezę refleksji poprzedników, a z drugiej strony - wkład w jej rozwój. Bogactwo egzegezy patrystycznej na zgłębiany temat nie pozwala zatrzymywać się nad każdym jej wątkiem, jednak zauważalne są pewne elementy określające miejsce Augustyna w tym względzie.

Z wykładni ojców wyłaniają się trzy podstawowe aspekty: eklezjologia, eschatologia i pareneza Jezusowej obietnicy. Innymi słowy, ojcowie starają się odpowiedzieć na pytanie: Kim jest tych ,wielu” przybywających z różnych stron świata do wspólnoty z patriarchami? Na czym będzie polegać owa wspólnota, określona w Ewangelii obrazem uczty? Jakie przesłanie moralne wynika z zapowiedzi Jezusa o powszechnym dostępie do zbawienia? W każdym z tych aspektów myśl Augustyna znajduje się w głównym nurcie tradycji.

Najbardziej powszechną interpretacją owej „wędrówki ludów” pozostaje interpretacja eklezjologiczna. Do królestwa Bożego dostają się poganie przyjmujący chrzest i uświęcający się w Kościele. Ireneusz z Lyonu stwierdza, że potomstwem Abrahamowym jest Kościół. On jest tą społecznością zasiadającą z Abrahamem i sprawiedliwymi Starego Przymierza do uczty niebieskiej. Analogicznie umiejscawia w przestrzeni eklezjalnej ów napływ wierzących do królestwa Bożego Orygenes. Twierdząc podobnie, Augustyn kontynuuje tę tradycję. Tak samo naucza Ambroży czy Hieronim. Już teraz następuje „,zwołanie" w imię Chrystusa ludzi ze wszystkich stron świata, a reszta dopełni się na końcu czasów. Wskazując na taką powszechność Kościoła, Ambroży nazywa go ecclesia magna.

${ }^{157}$ Grzegorz z Nyssy, Życie Mojżesza, II, 84, tłum. S. Kalinkowski, Kraków 2009, ŹMT 50, s. 55.

${ }^{158}$ Por. Pseudo-Klemens Rzymski, Homiliae, VIII, 4, ed. B. Rehm, Leipzig-Berlin 1953, GCS 42, s. 123. 
Podobnie jak Hieronim, Augustyn posiłkuje się biblijnym obrazem Syjonu, na którym według proroctw zbiorą się wszystkie ludy, oddając cześć jednemu Bogu. Biskup Hippony pragnie uwolnić ten obraz od podtekstów millenarystycznych, prawdopodobnie jeszcze występujących w jego czasach. W dyskusji być może z samym Ireneuszem z Lyonu, którego skądinąd w pismach kilkakrotnie przytacza jako miarodajny autorytet, wskazuje na czysto symboliczny charakter Jerozolimy. Tym medius locus, centrum świata, w gruncie rzeczy jest ciało Chrystusa, ale i ono nie jest tu rozumiane dosłownie, lecz właśnie w sensie Kościoła. Skądinąd, ślady polemiki antymillenarystycznej dostrzegamy u Augustyna w jego przestrodze przed zbyt cielesnym wyobrażeniem sobie uczty wespół z patriarchami. Takie zmysłowe wyobrażenie, zamiast pobudzać do walki o cnoty, utwierdza w wadach.

Wyłaniająca się z egzegezy ojców prawda o powszechności Kościoła zostaje ujęta w kategoriach geograficznych. Wiarę ogarniającą cały świat autorzy wiążą $\mathrm{z}$ sytuacją misyjną swoich czasów, dostrzegając $\mathrm{w}$ postępach Ewangelii znaki spełniania się Jezusowej obietnicy. W tym sensie Augustyn wyraża przekonanie, że rozwój chrześcijaństwa nie skończy się na jego ojczystej Afryce.

Pomysłową interpretacją przez Augustyna ,wielu” przychodzących „ze wschodu i zachodu" jest alegoryczne ich rozumienie jako dwóch stanów w Kościele, bezżennego i małżeńskiego. Chociaż alegoria odbiega od ścisłego kontekstu zapowiedzi Jezusa, to jednak pokazuje pragmatyzm komentatora, który potrafi aktualizować słowo, stosownie do potrzeb dyktowanych przez kaznodziejstwo czy polemikę.

Inny przykład skłonności alegorycznych spotykamy w Augustyńskiej wykładni dwunastki apostołów. W tej liczbie dopatruje się za Orygenesem pomnożenia czterech stron świata przez liczbę trzech Osób Boskich. Chociaż współczesnemu czytelnikowi tego rodzaju spekulacje mogą wydawać się obce, to pewnie inaczej były odbierane w tamtych czasach. Augustyn nie odrzuca alegorii i gotów jest, jak widzimy, korzystać z elementów egzegezy aleksandryjskiej.

Kiedy indziej z kolei wykładnia Augustyńska różni się od Orygenesowej. Obydwaj, i - wedle zachowanych świadectw - tylko oni, dłużej zatrzymując się nad słowem ,wielu” w Mt 8,11, podejmują dyskusję na temat powszechności zbawienia. Dochodzą przy tym do odmiennych wniosków, nie tyle na podstawie egzegezy, ile - ducha swojego myślenia. Zgodnie z koncepcją apokatastazy Orygenes liczy na zbawienie wszystkich, podczas gdy powodowany pewnym pesymizmem Augustyn przypuszcza, że jedynie jakaś mniejszość zostanie zbawiona.

Niewykluczone, że przeszłość manichejska Augustyna pozostawiła ślad na jego poglądach co do powszechności zbawienia. Spotykamy inny przypadek, 
w którym z kolei odrzucenie manicheizmu rzutuje na jego egzegezę rozpatrywanego logionu. W tym miejscu dotykamy kolejnego aspektu odnośnej teologii biblijnej, mianowicie eschatologii. W polemice z Faustusem, opowiadając się za jednością dwóch Testamentów, Augustyn zdecydowanie broni szlachetności i zasług Abrahama, które podważał manichejczyk. Abraham przed przyjściem Chrystusa nie przebywał za karę w żadnym piekle, ale był mężem sprawiedliwym, który już na początku uwierzył Bogu.

Interpretacja postaci Abrahama ma istotne znaczenie dla eschatologii wynikającej z Mt 8,11 i paraleli u Łukasza. To on w jakiś sposób staje się gospodarzem i głównym uczestnikiem uczty w królestwie Boga, do której zostaną dopuszczeni jego potomkowie. Augustyn powtarza za Pismem Świętym i Tradycją, że jego duchowymi potomkami są naśladowcy w wierze. Prawdę tę wyraził wcześniej Ireneusz z Lyonu językiem ścisłej teologii: przez Chrystusa Kościół zostaje adoptowany na potomstwo Abrahama i otrzymuje obiecane dziedzictwo.

W kontekście Łk 13,28-29 Augustyn wyjaśnia alegorycznie epizod z Jakubem i Ezawem, w którym młodszy syn ubiegł starszego w uzyskaniu ojcowskiego błogosławieństwa. Jakub jest jednym z patriarchów, w których towarzystwie będą ucztować przybyli do królestwa Bożego. Jakub symbolizuje Kościół, a Ezaw - Żydów. Chociaż w takiej interpretacji Augustyn nie jest oryginalny - stosuje ją kilkakrotnie na przykład Hieronim - to jednak biskup Hippony bodajże jako jedyny odwołuje się do niej w kontekście rozpatrywanego logionu.

Ojcowie ujmują chrystocentrycznie zapowiadaną ucztę z patriarchami. Abraham przyjmujący z pokorą tajemniczych gości zapowiada służebną swoją funkcję przy stole eschatologicznym. Ostatecznie to Chrystus jest gospodarzem uczty. Jak powtarza za Ewangelią między innymi Orygenes, tam będzie On pił ,kielich nowy” ze swoim uczniami. Zresztą, nawet i On ukaże się w postaci służebnej, gdyż będzie usługiwał swoim przy stole. Augustyn powtarza tego rodzaju prawdy. Nadaje im własną specyfikę, wskazując konsekwentnie na sprawiedliwość i mądrość jako pokarm, którym wszyscy będą się wtedy posilać. Owa cząstka, którą już za życia ziemskiego wybrała siostra Łazarza, Maria, będzie ciągle wzrastać.

Również w interpretacji przyszłej uczty jako spoczynku Augustyn idzie za swymi poprzednikami. Wywodzącym się z kultury grecko-rzymskiej autorom był bliski obraz ucztowania w połączeniu ze spoczynkiem w pozycji półleżącej. Biskup Hippony, jak inni, na przykład Euzebiusz z Cezarei, tego rodzaju spoczynek łączy z innym obrazem zażyłej wspólnoty z Abrahamem, mianowicie ze spoczynkiem na jego łonie. Zdaje się, że określenie przez Augustyna tego łona, a więc i eschatologicznego spoczynku, jako ,wiecznego odpoczynku na ustroniu u wielkiego Ojca" sięga istoty rzeczy. Pewnie dlatego zostało 
przejęte przez Grzegorza Wielkiego, Bedę Czcigodnego i niektórych pisarzy średniowiecznych.

W refleksji nad implikacjami moralnymi i duchowymi, które wynikają z obietnicy Jezusa, Augustyn chętnie posługuje się Pawłowym obrazem dziczki zaszczepionej w oliwkę. To, czego zabrakło Izraelitom, mianowicie wiara i pokora, staje się udziałem pogan zaszczepionych w drzewo wybranego przez Boga ludu. Bardziej niż inni autorzy biskup Hippony postrzega wiarę i pokorę w łączności z cnotą miłości, która dla niego jest korzeniem wszystkich cnót. Setnik, który uwierzył, jest ulubioną postacią naszego kaznodziei, często przytaczaną w kazaniach.

Analiza interpretacji przez ojców jednego logionu Jezusa pokazuje bogactwo patrystycznej refleksji układającej się w pewną całość, aczkolwiek niewolnej od pluralizmu i wewnętrznej dyskusji. Rozpatrując obietnicę Jezusa, biskup Hippony znalazł się w samym centrum tej egzegezy. Być może miejsce Augustyna tutaj oddaje jego miejsce w całej egzegezie patrystycznej.

\author{
"MANY WILL COME FROM EAST AND WEST [...]". \\ ST. AUGUSTINE'S INTERPRETATION OF MT 8,11 AND LK 13,28-29 \\ IN THE CONTEXT OF ANCIENT PATRISTIC EXEGESIS
}

\title{
SUMMARY
}

The article offers a complete overview of the Greek and Latin patristic exegesis of Mt 8,11 and Lk 13,28-29 with special focus on the exegetical commentaries of St. Augustine. Church Fathers underlined the ecclesiological dimension of Christ's eschatological promise. According to St. Augustine and other theologians, those who come "from east and west" are above all pagans who through faith and baptism become members of the Church. Some focus more on the stage of maturation of the Christian faith, thus those who "come from east and west" are the just and holy Christians who have perfected their faith. There is a difference of opinion between Origene and Augustine concerning the word „many”. It should be analyzed in the broader context of their reflections on the universality of salvation. Secondly, the patristic exegesis underlines the eschatological aspect of Christ' promise. The feast with the patriarchs symbolizes common heritage of faith and Christ is seen as the one who invites all the participants. Thirdly, there is a paranetical aspect of the patristic exegesis. Church Fathers expressed their reflections in the pastoral context, in homilies and spiritual conferences. They point to the quality of the humble faith of the centurion of Capharnaum, which guarantees a future participation in the eschatological feast with the patriarchs. 
Keywords: patristic exegesis, Augustine, patristic ecclesiology, patristic eschatology, universal salvation, eschatological feast, Abraham, Isaac, Jacob, four corners of the world, Mt 8,11, Lk 13,28-29

Słowa kluczowe: egzegeza patrystyczna, Augustyn, eklezjologia patrystyczna, eschatologia patrystyczna, uczta eschatologiczna, powszechność zbawienia, Abraham, Izaak i Jakub, cztery strony świata, Mt 8,11, Łk 13,28-29

\section{BIBLIOGRAFIA}

Agathangelus, Historia Armeniae, 23, ed. G. Lafontaine, La version grecque ancienne du livre Arménien d'Agathange, Louvain-la-Neuve 1973.

Ambroży z Mediolanu, De Abraham, 2, 9, 65, ed. C. Schenk1, Wien 1897, CSEL, 32/1.

Ambroży z Mediolanu, De excessu fratris Satyri, ed. O. Faller, Wien 1955, CSEL 73.

Ambroży z Mediolanu, Explanatio psalmorum XII, ed. M. Petschenig, Wien 1919, CSEL 64.

Ambroży Autpert, Expositio in Apocalypsin, ed. R. Weber, Turnhout 1975, CCM 27A.

Ambroży z Mediolanu, Expositio psalmi CXVIII, ed. M. Petschenig, Wien 1913, CSEL 62.

Ambroży z Mediolanu, O dobrach przynoszonych przez śmierć, thum. W. Szołdrski, Warszawa 1971, PSP 7.

Ambroży z Mediolanu, Wykład Ewangelii według św. Łukasza, tłum. W. Szołdrski, Warszawa 1977, PSP 16.

Anonim (Pseudo-Hieronim), Expositio Evangelii secundum Marcum, ed. M. Cahill, Turnhout 1997, CCL 82.

Anonim, Quaestiones vel Glosae in evangelio nomine Quaestiones vel Glosae, ed. R.E. McNally, Turnhout 1973, CCL 108B.

Apringiusz z Civitas Pacensis, Tractatus in Apocalypsin fragmenta quae supersunt, ed. R. Gryson, Turnhout 2003, CCL 107.

Atanazy Aleksandryjski, Epistulae festales, ed. L.Th. Lefort, Paris 1955, CSCO 151.

Augustyn z Hippony, Ad catholicos de secta Donatistarum, ed. M. Petschenig, Wien 1909, CSEL 52.

Augustyn z Hippony, Adversus Iudaeos, PL 42.

Augustyn z Hippony, Contra Cresconium, ed. M. Petschenig, Wien 1909, CSEL 52.

Augustyn z Hippony, Contra mendacium, ed. J. Zycha, Wien 1900, CSEL 41.

Augustyn z Hippony, Epistulae, ed. A. Goldbacher, Wien 1898, CSEL 34/2.

Augustyn z Hippony, Epistulae, ed. A. Goldbacher, Wien 1904, CSEL 44.

Augustyn z Hippony, Objaśnienia Psalmów, tłum. J. Sulowski, Warszawa 1986, PSP 38.

Augustyn z Hippony, Objaśnienia Psalmów, tłum. J. Sulowski, Warszawa 1986, PSP 41.

Augustyn z Hippony, Objaśnienia Psalmów, thum. J. Sulowski, Warszawa 1986, PSP 42/1.

Augustyn z Hippony, Przeciw Faustusowi [księgi I-XXI], tłum. J. Sulowski, Warszawa 1991, PSP 55.

Augustyn z Hippony, Przeciw Faustusowi [księgi XXII-XXXIII], thum. J. Sulowski, Warszawa 1991, PSP 56.

Augustyn z Hippony, Sermo de passione Domini (218 auctus), ed. R. Etaix, „Augustinianum” 34 (1994).

Augustyn z Hippony, Sermones, ed. C. Lambot, Turnhout 1961, CCL 41.

Augustyn z Hippony, Sermones, „Miscellanea Agostina”, t. 1, Roma 1930-1931.

Augustyn z Hippony, Sermones, 88, ed. P. Verbraken, „Revue Bénédictine” 94 (1984), s. 96. 
Augustyn z Hippony, Sermones, 111, ed. C. Lambot, „Revue Bénédictine” 57 (1947), s. 115.

Augustyn z Hippony, Sermones, PL 38.

Augustyn z Hippony, Sermones, PL 39.

Augustyn z Hippony, Wartości matżeństwa, tłum. W. Eborowicz, w: Antologia pism o matżeństwie i rodzinie, cz. 1, wyd. W. Eborowicz, Pelplin 1980, s. 86.

Bazyli z Seleucji, Sermones, PG 85.

Beatus z Liebany, Commentarius in Apocalipsin, ed. H.A. Sanders, Romae 1930.

Beda Czcigodny, In Lucae evangelium expositio, ed. D. Hurst, Turnhout 1960, CCL 120.

Beda Czcigodny, In primam partem Samuhelis libri IV. Nomina locorum, ed. D. Hurst, Turnhout 1962, CCL 119.

Beda Czcigodny, In principium Genesis usque ad nativitatem Isaac, ed. C.W. Jones, Turnhout 1967, CCL 118A.

Bird M.F., Who comes from the East and the West? Luke 13,28-29/ Matt 8,11-12 and the historical Jesus, „New Testament Studies” 52/4 (2006), s. 441-457.

Boring M.E., A proposed reconstruction of $Q$ 13,28-29, „Society of Biblical Literature Seminar Papers" 28 (1989), s. 1-22.

Cezary z Arles, Sermones Caesarii uel ex aliis fontibus hausti, ed. G. Morin, Turnhout 1953, CCL 104.

Chromacjusz z Akwilei, Tractatus in Mathaeum, ed. R. Étaix, J. Lemarié, Turnhout 1974, CCL 9A.

Cyprian z Kartaginy, O Modlitwie Pańskiej, 13, tłum. W. Kania, w: Odpowiedź na Słowo, wstęp i oprac. H. Pietras, Kraków 1993, s. 73.

Cyryl Aleksandryjski, Commentarii in Lucam, PG 72.

Cyryl Aleksandryjski, Glaphyra in Pentateuchum, PG 69.

Dupont J., 'Beaucoup viendront du levant et du couchant...' (Matt 8,11-12; Lk 13,28-29), „Sciences Ecclésiastiques"19/2 (1967), s. 153-168.

Epifaniusz Łaciński, Interpretatio Evangeliorum, ed. A. Erikson, Lund 1939.

Epiphanius' Treatise on Weights and Measures. The Syriac version, ed. J.E. Dean, Chicago 1935.

Epifaniusz z Salaminy, Panarion, ed. K. Holl, Leipzig Berlin 1915, GCS 25.

Euzebiusz z Cezarei, Commentaria in Psalmos, PG 23.

Euzebiusz z Cezarei, De ecclesiastica theologia, ed. E. Klostermann, G.C. Hansen, Leipzig-Berlin 1972 , GCS $14^{2}$.

Euzebiusz z Cezarei, Fragmenta varia, PG 24.

Euzebiusz z Cezarei, Theophania, ed. H. Gressmann, Leipzig-Berlin 1904, GCS 11/2.

Grimm W., Zum Hintergrund von Mt 8,11f/ Lk 1,28f, „Biblische Zeitschrift” 16/2 (1972), s. 255-256.

Grzegorz Wielki, Homiliae in evangelia, ed. R. Etaix, Turnhout 1999, CCL 141.

Grzegorz Wielki, Homilie na Ewangelie, b. thum., Warszawa 1998.

Grzegorz Wielki (?), In librum primum Regum expositionum libri VI, ed. P. Verbraken, Turnhout 1963, CCL 144.

Grzegorz z Elwiry, Tractatus Origenis de libris Sanctarum Scripturarum, ed. V. Bulhart, Turnhout 1967, CCL 69.

Grzegorz z Nyssy, Życie Mojżesza, thum. S. Kalinkowski, Kraków 2009, ŹMT 50.

Hieronim ze Strydonu, Commentarii in Isaiam, ed. M. Adriaen, Turnhout 1963, CCL 73.

Hieronim ze Strydonu, Commentarii in Isaiam, ed. M. Adriaen, Turnhout 1963, CCL 73A.

Hieronim ze Strydonu, Commentarii in prophetas minores, ed. M. Adriaen, Turnhout 1969, CCL 76.

Hieronim ze Strydonu, Commentarii in prophetas minores, ed. M. Adriaen, Turnhout 1970, CCL $76 \mathrm{~A}$.

Hieronim ze Strydonu, In Hieremiam prophetam, ed. S. Reiter, Wien 1960, CSEL 74.

Hieronim ze Strydonu, Listy, tłum. J. Czuj, M. Ożóg, Kraków 2010, ŹMT 55.

Hieronim ze Strydonu, Listy, tłum. J. Czuj, M. Ożóg, Kraków 2011, ŹMT 63.

Ireneusz z Lyonu, Adversus haereses, ed. A. Rousseau, L. Doutreleau, Paris 1974, SCh 211. 
Ireneusz z Lyonu, Adversus haereses, ed. A. Rousseau, B. Hemmerdinger, L. Doutreleau, Paris 1965, SCh 100.

Ireneusz z Lyonu Adversus haereses, ed. A. Rousseau, L. Doutreleau, C. Mercier, Paris 1969, SCh 153.

Jan Chryzostom, Ad viduam iuniorem, ed. G. H. Ettlinger, B. Grillet, Paris 1968, SCh 138.

Jan Chryzostom, De virginitate, ed. H. Musurillo, B. Grillet, Paris 1966, SCh 125.

Jan Chryzostom, Homilie na Ewangelię wedtug św. Mateusza, tłum. J. Krystyniacki, A. Baron, Kraków 2000, ŹMT 18.

Jan Chryzostom, Homilie na List św. Pawła do Rzymian, tłum. T. Sinko, t. 1, cz. 1, Kraków 1995.

Jan Chryzostom, In Isaiam, PG 56.

Justyn Męczennik, Dialog z Żydem Tryfonem, tłum. L. Misiarczyk, Warszawa 2012.

Kasjodor, Expositio sancti Pauli Epistulae ad Romanos, PL 68.

Liber questionum in evangeliis. De interpretatione nominum, ed. J. Rittmueller, Turnhout 2003, CCL 108F.

Metody z Olimpu, Uczta, tłum. S. Kalinkowski, Warszawa 1980, PSP 24.

Orygenes, Commentarii in Matthaeum (fragmenta), ed. E. Klostermann, E. Benz, Leipzig 1941, GCS 41/1.

Orygenes, Homilie o Księdze Jozuego, thum. S. Kalinkowski, Warszawa 1986, PSP 34/2.

Orygenes, Homilie o Księdze Liczb, tłum. S. Kalinkowski, Warszawa 1986, PSP 34/1.

Orygenes, Homilie o Księdze Rodzaju, tłum. S. Kalinkowski, Warszawa 1984, PSP 31/1.

Orygenes, Komentarz do Ewangelii według św. Jana, tłum. S. Kalinkowski, Kraków 2003, ŹMT 27.

Orygenes, Komentarz do Listu św. Pawła do Rzymian, tłum. S. Kalinkowski, Warszawa 1994, PSP $57 / 1$.

Orygenes, Komentarz do Pieśni nad Pieśniami, thum. S. Kalinkowski, Kraków 1994.

Orygenes, Scholia in Lucam, PG 72.

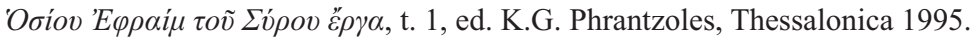

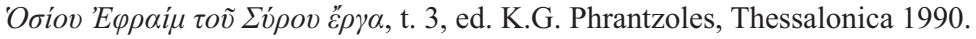

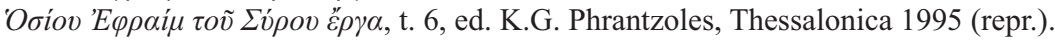

Piotr Chryzolog, Collectio sermonum, ed. A. Olivar, Turnhout 1975, CCL 24.

Prokop z Gazy, Commentarii in Octateuchum, PG 87/1.

Pseudo-Hipolit Rzymski, De consummatione mundi, ed. H. Achelis, Leipzig-Berlin 1897, GCS 1/2. Pseudo-Klemens Rzymski, Homiliae, ed. B. Rehm, Leipzig-Berlin 1953, GCS 42.

Pseudo-Klemens Rzymski w przekł. Rufina z Akwilei, Recognitiones, ed. B. Rehm, F. Paschke, Leipzig 1965, GCS 51.

Sancti Aurelii Augustini Sermones selecti duodeviginti, ed. C. Lambot, Utrecht 1950, SPM 1.

Sancti patris nostri Cyrilli archiepiscopi Alexandrini in D. Joannis evangelium, t. 1, ed. P.E. Pusey, Oxford 1872.

Zeller D., Das Logion Mt 8,11f/ Lk 13,28f und das Motiv der 'Völkerwallfahrt', „Biblische Zeitschrift" 15/2 (1971), s. 222-237.

O. DR HAB. LEON NiEŚCIOR, PROF. UKSW - wykładowca teologii patrystycznej, kierownik Katedry Teologii Patrystycznej na Wydziale Teologicznym UKSW w Warszawie, redaktor „E-Patrologos”, jego zainteresowania badawcze obejmują monastycyzm i misje starożytne oraz egzegezę patrystyczną. Ostatnio opublikował monografię Mowa misyjna w interpretacji patrystycznej, Wydawnictwo Papieskiego Wydziału Teologicznego, Wrocław 2013. 